\title{
A bajor feszületügy: a Bundesverfassungsgericht egyik legnagyobb krízise
}

\section{PÓCZA KÁLMÁN ${ }^{1}$}

A Német Szövetségi Alkotmánybíróság (Bundesverfassungsgericht) kétségkivül az egyik legnagyobb tekintéllyel bíró testület Németországban, sőt szinte egész Európában. Döntései és maga az intézmény is széles körü támogatottságot élveznek a német állampolgárok körében. Ez a tekintély és a magas bizalmi index együttesen oda vezetett, hogy döntéseivel a politikai elit tagjai csak nagyon ritkán mertek szembeszegülni. Ezen ritka alkalmak egyike 1995ben a bajor feszületügyben meghozott döntésük volt, amikor bajor politikusok nemcsak a döntést és az alkotmánybiróság intézményét kritizálták nyiltan, hanem több tízezres tömegtüntetésen a birósági döntés figyelmen kivül hagyására szólitottak fel. Jelen tanulmány tanulmány annak kíván utánajárni, hogy milyen okok vezettek a német alkotmánybíróság II. világháború utáni legnagyobb kriziséhez, hogy miért pont a vallásszabadság alapvetö emberi joga és az iskolai feszületek kérdése destabilizálta (átmenetileg) a német alkotmánybíróság helyzetét.

Kulcsszavak: alkotmánybíráskodás, Bundesverfassungsgericht, feszület, Bajorország

\section{The Bavarian Crucifix Case: One of the Biggest Crises of the Bundesverfassungsgericht}

The German Federal Constitutional Court (GFCC) is certainly one of the most respected institutions in Germany and beyond. The court and its decisions enjoy a high level of public support among German citizens, which implicates that the political elite has almost always complied with the tenor of the court's decisions. Nevertheless, political leaders felt sometimes encouraged to evade the command of the GFCC. One of these rare occasions was the so-called Kruzifix decision from 1995 when Bavarian politicians have not only openly criticised the court but called upon resistance against the court decision during a public demonstration in Munich with more than 20,000 participants. The present study will disclose the causes that led to

1 Tudományos főmunkatárs, NKE Eötvös József Kutatóközpont, Politika- és Államelméleti Kutatóintézet; tudományos főmunkatárs, ELKH Társadalomtudományi Kutatóközpont; e-mail: pocza.kalman@uni-nke.hu 
one of the greatest crises of the FCC since 1945, and focus on the question why the position of the FCC has been (temporarily) destabilised by the issue of the crucifix in the classroom and the question of freedom of religion.

Keywords: constitutional adjudication, German Federal Constitutional Court, crucifix, Bavaria

A német alkotmánybíróság (Bundesverfassungsgericht, BVerfG) igen nagy tekintélylyel bír nemcsak Németországban, hanem szinte egész Európában. Bár az Európai Központi Bank kötvényvásárlási programja kapcsán hozott döntését (2 BvR 859/15) széles körben kritizálták Európában, bizalmi válságról (legalábbis a német lakosság körében) egyelőre nem lehet szó ennek kapcsán. Hogy az európai intézményekkel (Európai Központi Bank, Európai Unió Bírósága) vállalt nyílt konfliktus és az ezt övező kritikák mennyiben befolyásolják majd hosszabb távon a német állampolgárok vélekedését saját alkotmánybíróságukról, az egyelőre valóban a jövő zenéje. Másrészt az is bizonyos, hogy a BVerfG társadalmi támogatottsága a kezdetekben korántsem volt erősnek mondható. Ez részben annak volt köszönhető, hogy a német állampolgárok egy része nem is ismerte az intézményt, részben viszont az Adenauer-kormánnyal vállalt súlyos konfliktusai miatt sem övezte olyan széles körű elismerés a német lakosság körében az 1950-es években, mint a későbbiek folyamán. ${ }^{2}$ Hogy miként is sikerült aztán komoly tekintélyre szert tennie a bíróságnak, az kétségkívül izgalmas kérdés, ám szétfeszítené a jelen tanulmány kereteit. ${ }^{3}$ Ebben az írásban ugyanis arra a kérdésre keressük a választ, hogy mi lehet az oka annak, hogy politikai szereplők nyílt konfliktust is felvállalva kerülik meg a nagy tekintélyü BVerfG döntését.

A vizsgált eset a bíróság 1995-ös úgynevezett Kruzifix-döntése (1 BvR 1087/91), ez a döntés ugyanis korábban még soha nem tapasztalt ellenállási hullámot váltott ki Németországban a szövetségi alkotmánybíróság döntésével szemben. A Kruzifixdöntés vizsgálata két szempontból is relevánsnak tünik. Egyrészt ez volt ugyan-

2 A bíróság korai történetéhez l. Pócza Kálmán: Politika és alkotmánybíróság: a Bundesverfassungsgericht létrejötte. Külügyi Szemle, 13. (2014), 1. 111-131.

3 A tekintély és a társadalmi támogatottság kiépítéséről a BVerfG vonatkozásában l. Werner J. Patzelt: Warum mögen die Deutschen ihr Verfassungsgericht so sehr? In Robert C. van Ooyen - Martin H. W. Möllers (szerk.): Handbuch Bundesverfassungsgericht im politischen System. Wiesbaden, Springer Fachmedien, 2015. Általában a bíróságok vonatkozásában 1. Georg Vanberg: The Politics of Constitutional Review in Germany. Political Economy of Institutions and Decisions. Cambridge, Cambridge University Press, 2005. 21.; Georg Vanberg: Establishing and Maintaining Judicial Independence. In Gregory A. Caldeira et alii (szerk.): The Oxford Handbook of Law and Politics. Oxford, Oxford University Press, 2008; Georg Vanberg: Constitutional Courts in Comparative Perspective: A Theoretical Assessment. Annual Review of Political Science, 18. (2015), 1. 167-185. 177.; Philipp A. Schroeder: The Political Constraints on Constitutional Review. Doktori értekezés, 2019, 20. Elérhető: https://discovery.ucl.ac.uk/id/eprint/10078526 (A letöltés dátuma: 2020. 10. 05.); Brandon L. Bartels - Eric Kramon: Does Public Support for Judicial Power Depend on Who Is in Political Power? Testing a Theory of Partisan Alignment in Africa. American Political Science Review, 114. (2020), 1. 144-163. 
is a Német Szövetségi Köztársaság II. világháború utáni történetében mindmáig az egyetlen olyan eset, amikor politikusok és a német választópolgárok jelentős része több tízezres tüntetésen adtak hangot igencsak kritikus véleményüknek az alkotmánybíróság döntésével kapcsolatban, sőt nyíltan ellenállásra szólítottak fel. Ennek eredménye tulajdonképpen az lett, hogy a BVerfG döntését bizonyos értelemben elszabotálták: hiába döntött úgy a bíróság, hogy a bajor állami közoktatási intézmények faláról le kell venni a kereszteket, azok mind a mai napig ott lógnak a tantermek falán Bajorországban. Másrészt azért is releváns a téma vizsgálata, mert a feszületügy Bajorországban ma is a közéleti viták középpontjában áll. Ezt jól mutatja az is, hogy Markus Söder, a CSU tartományi miniszterelnök-jelöltje a 2018-as bajor tartományi választási kampány nyitányaként arra tett ígéretet, hogy győzelmük esetén immáron nemcsak az iskolatermekben lesz kötelező kifüggeszteni a keresztet, hanem az összes bajor állami hivatalban is.

Az alábbiakban előbb a bírósági döntések végrehajtására és teljesülésére vonatkozó elméleti szakirodalom megállapításaira térek ki, ezekre alapozva fogalmazok meg négy hipotézist. Az elméleti szakirodalom szerint ugyanis a magas társadalmi támogatottságot élvező alkotmánybíróságok döntéseit a többi intézményi szereplő azért hajtja végre, mert tartanak a választópolgárok negatív reakcióitól. Másként fogalmazva, a politikai szereplők számára azért nem érdemes nyíltan (vagy kevésbé nyíltan) elszabotálni a választópolgárok körében nagy elismertségnek örvendő alkotmánybíróság döntését, mert az komoly szavazatveszteséggel járhat a következő választásokon. Érdekes módon azonban a feszületügyben ez a hipotézis egyáltalán nem állta meg a helyét, ráadásul úgy tünik, hogy a racionális döntéselméleti modellek meg sem kísérelték megmagyarázni e deviancia okait. A kutatás módszertanának rövid bemutatását követően felvázolom a Kruzifix-döntés történelmi kontextusát, számba veszem a döntésre adott válaszreakciókat, illetve megvizsgálom, hogy tényleg beszélhetünk-e a döntés végrehajtásának elszabotálásáról. Megállapítom továbbá, hogy az elméleti szakirodalomban megfogalmazott hipotéziseket a választott eset cáfolja. Ezt követően alternatív magyarázatot kínálok a deviáns esetnek számító Kruzifix-döntésre.

\section{Elméleti szakirodalom és hipotézisek}

A klasszikus megállapítás szerint a bíróság saját döntéseinek kikényszerítéséhez szükséges eszközökkel egyáltalán nem rendelkezik, többek között ezért is tartják a legveszélytelenebb hatalmi ágnak. Alexander Hamilton a Föderalista 78. írásában így érvel:

„A végrehajtó hatalmi ág nemcsak a tisztségeket osztja el, hanem a közösség kardját is a kezében tartja. A törvényhozó hatalmi ág nem csak a pénztárcával rendelkezik, hanem megszabja a minden polgár kötelességeit és jogait szabályozó rendelkezéseket is. A bírói hatalmi ágnak ezzel szemben nincs befolyása sem a kardra, 
sem a kasszára [...]. S végső fokon még az ítéletei hathatóssága szempontjából is a végrehajtó ág erős karjára kell támaszkodnia." ${ }^{4}$

Amire Hamilton a bírósági ítéletek „hathatósságaként” utalt, az a modern szakirodalmi nyelvezetben tulajdonképpen a bírósági döntések teljesülését (compliance) jelenti. Mivel a bíróságnak nincsenek eszközei (pénze vagy fegyvere) ahhoz, hogy kikényszerítse döntéseinek végrehajtását, tulajdonképpen a végrehajtó és a törvényhozó hatalom erejére kell támaszkodnia, márpedig ez utóbbiak szempontjából nézve egyáltalán nem egyértelmü, hogy miért is kényszerítenék ki vagy engedelmeskednének olyan bírósági döntéseknek, amelyek nem előnyösek számukra.

A modern szakirodalomban a bírósági döntések végrehajtásának vagy teljesülésének okait vizsgálva kétféle megközelítés érvényesül. Az instrumentális elmélet szerint az érintett szereplők azért hajtják végre a bíróság döntését, mert az saját jól felfogott (ám önös) politikai érdekükben áll. A normaalapú megközelítés szerint viszont azért hajtják végre a politikai szereplők a bírósági döntéseket, mert a legitim hatalommal szemben a normakövető magatartás az alapbeállítódás. ${ }^{5}$ Ez utóbbi megközelítés ugyan nem a fósodor megközelítései közé tartozik, ráadásul magyarázóereje azért valamivel gyengébbnek tűnik, de azt is látni kell, hogy a normakövető magatartás idővel kialakulhat akkor is, ha eredetileg csak jól felfogott önérdekből hajtották végre a bírósági döntéseket. ${ }^{6}$

Az instrumentális megközelítés szerint a bíróság maga is tudja némileg befolyásolni azt, hogy teljesül-e mindaz, amit a döntésükben elrendeltek: a döntés indokolásának meggyőző ereje, nyelvezetének egyértelműsége vagy homályossága például befolyásolhatja azt, hogy elfogadják-e a politikai szereplök. ${ }^{7}$ Ugyanez igaz a döntés hatályával kapcsolatban is: ha a döntésüknek csak jövőbeli hatálya van, akkor nagyobb lehet az esély arra, hogy teljesül. ${ }^{8}$ Ugyanakkor csökkentheti a sikeres teljesülés esélyeit, ha különvéleményeket fogalmaznak meg a bírák, vagy csak nagyon kis többséget sikerült a bíróságon belül a többségi döntés mögé állítani. ${ }^{9}$ Másrészt növeli a teljesülés esélyét, ha módjában áll a bíróságnak olyan monitoringtestületet létrehoznia, amelyik figyelemmel kíséri a döntés végrehajtását. Stratégiailag lehetősége van a bíróságnak a teljesülés befolyásolására azáltal, hogy nyilvános meghallgatásokat tart, és így ke-

4 John Jay - Alexander Hamilton - James Madison: A föderalista. Budapest, Európa, 1998. 553.

5 Diana Kapiszewski - Matthew M. Taylor: Compliance: Conceptualizing, Measuring, and Explaining Adherence to Judicial Rulings. Law \& Social Inquiry, 38. (2013), 4. 803-835. 819.

6 Uo. 822.

7 Jeffrey K. Staton - Georg Vanberg: The Value of Vagueness: Delegation, Defiance, and Judicial Opinions. American Journal of Political Science, 52. (2008), 3. 504-519. 515.; Sebastian Sternberg: No Public, no Power? Analyzing the Importance of Public Support for Constitutional Review with Novel Data and Machine Learning Methods. Doktori értekezés, 2019, 141. Elérhető: https://madoc. bib.uni-mannheim.de/5232 (A letöltés dátuma: 2020. 10. 05.)

8 Alexei Trochev: Judging Russia: The Role of the Constitutional Court in Russian Politics 1990-2006. Cambridge, Cambridge University Press, 2008. 23.

9 James F. Spriggs: Explaining Federal Bureaucratic Compliance with Supreme Court Opinions. Political Research Quarterly, 50. (1997), 3. 567-593. 571. 
rül a médiaérdeklődés középpontjába, vagy éppen a választási kampányidőszakban hozza meg a döntését, amikor minden fontos politikai ügynek sokkal nagyobb hatása lehet. ${ }^{10} \mathrm{~A}$ döntés teljesülését befolyásolhatja az is, hogy kire vonatkozik a döntés, milyen szervnek kell cselekednie, milyen komplex módon kell cselekednie, milyen mértékben kell újraszabályoznia az érintett területet. Ha csak egyetlen szereplőnek egy viszonylag egyszerü folyamat révén kell viszonylag keveset változtatnia a fennálló helyzeten, akkor nyilvánvalóan sokkal nagyobb az esélye a teljesülésnek, mint ha több, komplex szervezetnek komplex folyamatok révén sok dolgot meg kell változtatnia. ${ }^{11} \mathrm{Az}$ érintett politikai szereplők pedig néha maguk is abban érdekeltek, hogy inkább a bíróság döntsön kényes kérdésekben, az övé legyen a felelősség. ${ }^{12}$

A szakirodalomban ezeken túlmenően az egyik legdominánsabb modell ugyanakkor a racionális döntéselmélet belátásaira alapozva abból indul ki, hogy a bírósági döntések akkor fognak a legnagyobb eséllyel teljesülni, ha a bíróság jelentős társadalmi támogatottságot élvez, és megfelelő módon láthatóvá tudja tenni döntését a közvélemény számára, vagyis a közvélemény felfigyel, és figyelemmel követi a bíróság döntését. ${ }^{13}$ A racionális döntéselméleti modell szerint ugyanis ebben az esetben a politikai szereplőknek az lesz a racionális önérdekük, hogy elfogadják a bíróság döntését, ellenkező esetben ugyanis a választók könnyen megbüntethetik a következő választás alkalmával őket. Ha a lakosság körében nagy támogatottságnak és elismertségnek örvendő testület döntését nem hajtja végre az érintett politikai szereplö, és ez a nyilvánosságban komoly visszhangot kelt, akkor a választópolgárok jó eséllyel megvonják szavazatukat a bírósági döntésnek ellenszegülő vagy azt nyíltan (esetleg bújtatottan)

10 Jay N. Krehbiel: The Politics of Judicial Procedures: The Role of Public Oral Hearings in the German Constitutional Court. American Journal of Political Science, 60. (2016), 4. 990-1005.; Jay N.

Krehbiel: Elections, Public Awareness, and the Efficacy of Constitutional Review. Journal of Law and Courts, 7. (2019), 1. 53-79.

11 Spriggs i. m. (9. lj.).

12 Mark A. Graber: The Nonmajoritarian Difficulty: Legislative Deference to the Judiciary. Studies in American Political Development, 7. (1993), 1. 35-73.; George I. Lovell: Legislative Deferrals: Statutory Ambiguity, Judicial Power, and American Democracy. Cambridge, Cambridge University Press, 2003; Scott E. Lemieux - David J. Watkins: Beyond the "Countermajoritarian Difficulty": Lessons from Contemporary Democratic Theory. Polity, 41. (2009), 1. 30-62.

13 Vanberg, Georg: Legislative-Judicial Relations: A Game-Theoretic Approach to Constitutional Review. American Journal of Political Science, 45. (2001), 2. 346-361.;Vanberg 2005 i. m. (3. lj.); Vanberg 2015 i. m. (3. lj.); Tom S. Clark: The Limits of Judicial Independence: Political Economy of Institutions and Decisions. Cambridge, Cambridge University Press, 2010. 17. és 159.; Krehbiel 2016 i. m. (10. lj.); Krehbiel 2019 i. m. (10. lj.); Sebastian Sternberg et alii: Zum Einfluss der öffentlichen Meinung auf Entscheidungen des Bundesverfassungsgerichts. Eine Analyse von abstrakten Normenkontrollen sowie Bund-Länder-Streitigkeiten 1974-2010. Politische Vierteljahresschrift, 56. (2015), 4. 570-598. 574.; Clifford J. Carrubba - Christopher J. Zorn: Executive Discretion, Judicial Decision Making, and Separation of Powers in the United States. Journal of Politics, 72. (2010), 3. 812-824.; Matthew E. K. Hall: The Semiconstrained Court: Public Opinion, the Separation of Powers, and the US Supreme Court's Fear of Nonimplementation. American Journal of Political Science, 58. (2014), 2. 352-366.; Kevin T. McGuire - James A. Stimson: The Least Dangerous Branch Revisited: New Evidence on Supreme Court Responsiveness to Public Preferences. Journal of Politics, 66. (2004), 4. 1018-1035. 
elszabotáló szereplőktől. ${ }^{14}$ Ennek a felvetésnek az a kiindulópontja, hogy a bíróságok ugyan sem pénzzel, sem fegyverrel nem rendelkeznek, ám a magas társadalmi támogatottság és döntéseik széles körü tematizálása a nyilvánosságban együttesen kellő erélyt és tekintélyt biztosít számukra ahhoz, hogy „kikényszerítsék” a politikai szereplők engedelmességét, vagy legalább ahhoz, hogy azok ne merjenek szembeszegülni valamilyen formában a bírósági döntéssel. Fordítva olvasva a történetet pedig azt a hipotézist is fel lehet állítani e racionális döntéselméleti modellek révén, hogy a nagy társadalmi támogatottsággal rendelkező bíróságok döntéseivel szemben ellenszegülni, azokat elszabotálni egészen egyszerủen túl nagy politikai költséggel járhat a politikai szereplők számára. ${ }^{15}$

Ahhoz, hogy ezt a diffúz társadalmi támogatottságot meg tudja őrizni, és ezáltal a többi hatalmi ág engedelmességét biztosítani tudja, a bíróságnak nagyon kell figyelnie arra, hogy módszeresen és rendszeresen ne menjen szembe a társadalom többségének a véleményével. ${ }^{16}$ Ez viszont oda vezet(het), hogy a bíróság valójában inkább a többségi akarat megtestesítője lesz, az Alexander Bickel által megfogalmazott úgynevezett többségellenes normatív probléma (counter-majoritarian difficulty) ${ }^{17}$ pedig valójában nem is valós problémája a bíróságoknak, hiszen az empirikus adatok azt mutatják, hogy a bíróság inkább a társadalom többségével egyetértve, a többségi véleményt tükröző döntéseket szokott hozni. Erre a tényre nemcsak az amerikai Legfelsőbb Bíróság kapcsán hívta fel a figyelmet a szakirodalom, ${ }^{18}$ de a BVerfG kapcsán is ugyanerre a megállapításra jutottak kvantitatív és kvalitatív munkák is. ${ }^{19}$

14 Vanberg (2005) i. m. (3. lj.) 176.

15 Persze ezekkel a feltételezésekkel sok probléma van: az egyik, hogy a bíróságokról általában azt feltételezik, hogy magas a társadalmi támogatottságuk, de általában olyan bíróságokra fókuszálnak csak a kutatások, amelyek esetében ez tényleg igaz. Az ilyen esetek ugyanakkor jelenthetik a kivételt is [Amanda Driscoll - Michael J. Nelson: The Costs and Benefits of Court Curbing: Experimental Evidence from the United States. 2018, 5. Elérhető: https://pdfs.semanticscholar.org/ d2b8/ab6532c4957339bd52d7ad0897b3f425fa73.pdf (A letöltés dátuma: 2020. 10. 05.); Sternberg i. m. (7. lj.) 9.]. A francia alkotmánytanács jóval kisebb társadalmi támogatottsággal bír, mint a német, ennek megfelelően jóval kisebb a mozgástere is, és döntéseinek végrehajtása is jóval kérdésesebb [Sternberg i. m. (7. lj.) 139].

16 Sternberg et alii i. m. (13. lj.) 589.; Sternberg i. m. (7. lj.) 4.

17 Alexander M. Bickel: The Least Dangerous Branch: The Supreme Court at the Bar of Politics. Indianapolis, Bobbs-Merrill, 1962. 16.

18 Robert A. Dahl: Decision-Making in a Democracy: The Supreme Court as a National PolicyMaker. Journal of Public Law, 6. (1957), 2. 279-295.; Clark i. m. (13. lj.) 160.; Jonathan P. Kastellec: Empirically Evaluating the Countermajoritarian Difficulty: Public Opinion, State Policy, and Judicial Review before Roe v. Wade. Journal of Law and Courts, 4. (2016), 1. 1-42.; Whittington, Keith E.: "Interpose Your Friendly Hand": Political Supports for the Exercise of Judicial Review by the United States Supreme Court. American Political Science Review, 99. (2005), 4. 583-596.; Sternberg et alii i. m. (13. lj.) 589.

19 A kvantitatív munkákhoz l. Vanberg 2005 i. m. (3. lj.); Sternberg et alii i. m. (13. lj.). A kvalitatív munkához l. Uwe Kranenpohl: Hinter dem Schleier des Beratungsgeheimnisses: Der Willensbildungs- und Entscheidungsprozess des Bundesverfassungsgerichts. Wiesbaden, VS Verlag für Sozialwissenschaften, 2010. 
Másrészt viszont (többek között éppen a BVerfG döntései kapcsán is) megvizsgálták azt az esetet is, amikor nemcsak az alkotmánybíróság bír magas társadalmi támogatottsággal, hanem az inkumbens politikai erő is jó okkal számít arra, hogy magas társadalmi támogatottsága miatt a következő választás(ok) alkalmával is kormányon tartják a választópolgárok. ${ }^{20} \mathrm{Ez}$ utóbbi eset önkorlátozásra intheti a bíróságot, mivel attól tarthat, hogy a döntését a népszerű politikai szereplők valamilyen módon elszabotálják majd. ${ }^{21}$

Az empirikus adatok inkább azt támasztják alá, hogy a bíróságok hajlamosak a többségi véleménnyel megegyező döntést hozni, ${ }^{22}$ de az utóbbi időben komolyabbnak tűnő elméleti érveket, sőt néhány esetben empirikus példákat is felsorakoztattak arra, hogy milyen feltételek esetén játszik fontos szerepet a bíróságok önkorlátozása. ${ }^{23}$ A politikai szereplők deferens magatartása ugyanis abban az esetben nem feltétlenül biztosított, ha a választók szoros pártkötődése és pártjuk melletti elköteleződése felülírja a bíróság magas társadalmi támogatottságát, ami oda vezethet, hogy a választópolgárok egy része mégiscsak helyeselheti a bírósági döntés elszabotálását, amennyiben azt kedvenc pártja teszi. Éppen ezért nem megbüntetni, hanem egyenesen jutalmazni fogja kedvenc pártját ilyen esetekben. ${ }^{24} \mathrm{Ez}$ a tézis tehát azt állítja,

20 Matthew E. K. Hall - Joseph D. Ura: Judicial Majoritarianism. Journal of Politics, 77. (2015), 3. 818-832.; Schroeder i. m. (3. li.) 51.

21 Mario Bergara - Barak Richman - Pablo T. Spiller: Modeling Supreme Court Strategic Decision Making: The Congressional Constraint. Legislative Studies Quarterly, 28. (2003), 2. 247-280; Tom S. Clark: The Separation of Powers, Court Curbing, and Judicial Legitimacy. American Journal of Political Science, 53. (2009), 4. 971-989.; Hall i. m. (13. lj.); Michael A. Bailey - Forrest Maltzman: The Constrained Court: Law, Politics, and the Decisions Justices Make. Princeton, Princeton University Press, 2011; Schroeder i. m. (3. lj.) 48.

22 Amerikai vonatkozásban l. William Mishler - Reginald S. Sheehan: The Supreme Court as a Countermajoritarian Institution? The Impact of Public Opinion on Supreme Court Decisions. American Political Science Review, 87. (1993), 1. 87-101.; Barry Friedman: The Will of the People: How Public Opinion has Influenced the Supreme Court and Shaped the Meaning of the Constitution. New York, Farrar, Straus and Giroux, 2009; Lee Epstein - Andrew Martin: Does Public Opinion Infuence the Supreme Court? Possibly Yes (But We're not Sure Why). University of Pennsylvania Journal of Constitutional Law, 13. (2010), 2. 263-281.; Christopher J. Casillas - Peter K. Enns - Patrick C. Wohlfarth: How Public Opinion Constrains the US Supreme Court. American Journal of Political Science, 55. (2011), 1. 74-88.; Kastellec i. m. (18. lj.); Hall-Ura i. m. 20. lj.). Német vonatkozásban l. Rudolf Gerhard: Die Medien haben Einfluss auf die Justiz - aber welchen? Eine Umfrage und ihre Ergebnisse. In Organisationsbüro der Strafverteidigervereinigungen (szerk.): Erosion der Rechtsstaatlichkeit: Werteverfall oder Paradigmenwechsel? Berlin, Schriftenreihe der Strafverteidigervereinigungen, 2002; Hans M. Kepplinger - Thomas Zerback: Der Einfluss der Medien auf Richter und Staatsanwälte. Publizistik, 54. (2009), 2. 216-239.; Christoph Hönnige - Thomas Gschwend: Das Bundesverfassungsgericht im politischen System der BRD - ein unbekanntes Wesen? Politische Vierteljahresschrift, 51. (2010), 3. 507-530.

23 Jeffrey K. Staton: Judicial Policy Implementation in Mexico City and Mérida. Comparative Politics, 37. (2004), 1. 41-60.; Amanda Driscoll - Michael J. Nelson: Judicial Selection and the Democratization of Justice: Lessons from the Bolivian Judicial Elections. Journal of Law and Courts, 3. (2015), 1. 115-148.; Gretchen Helmke: Institutions on the Edge: The Origins and Consequences of Inter-Branch Crises in Latin America. Cambridge, Cambridge University Press, 2017; Schroeder i. m. (3. lj.) 32.

24 Bartels-Kramon i. m. (3. lj.); Driscoll-Nelson i. m. (15. lj.) 32. 
hogy a választópolgárok pártkötődésük függvényében viszonyulnak a bírósághoz: ha a bíróság előmozdítja kedvenc pártjuk agendáját, akkor legitim intézménynek tartják és támogatják, ha viszont nem, akkor támogatásukat is megvonják a bíróságtól. ${ }^{25}$ Ebből következőleg egy olyan kormányzó párt vagy koalíció, amelynek szavazótábora szorosan kötődik kedvenc pártjához, könnyebben szabotálja el a bíróság döntését, mivel nem kell tartania a választók elpártolásától. ${ }^{26}$

Az elméleti szakirodalom fentebbi megállapításaira támaszkodva két főhipotézist és két alhipotézist lehet megfogalmazni:

1. ha bíróságok fenn kívánják tartani diffúz társadalmi támogatottságukat, akkor a bírósági döntésekben a társadalom többségének a véleménye fog tükröződni;

1.1. ha a politikai többség jó okkal számít arra, hogy hatalomban maradhat, akkor a bírósági döntésekben a politikai többség véleménye fog tükröződni;

2. ha nagy társadalmi támogatottsággal rendelkeznek a bíróságok, akkor a politikai szereplők végrehajtják a bírósági döntéseket;

2.2. ha a politikai többség erősen elkötelezett támogatókkal rendelkezik, akkor a politikai szereplők szembeszegülnek a bírósági döntésekkel.

\section{A vizsgálat módszertana}

Az alábbiakban az elméleti szakirodalom alapján megfogalmazott négy hipotézist egy esettanulmány bemutatásával kívánjuk tesztelni. Elöljáróban annyit elmondhatunk, hogy az eset a négy hipotézis közül hármat megcáfol, a negyedik hipotézis kapcsán pedig további okfejtésekre lesz szükség, éppen ezért a Kruzifix-ügy egyértelmüen deviáns esetnek fog számítani.

Deviáns esetek oksági magyarázatánál a folyamatkövetés (process tracing) módszere tủnik egyértelmủen a legjobb módszertani megoldásnak. ${ }^{27} \mathrm{~A}$ deviáns esetekre általában a nagy esetszámmal dolgozó, átfogó elméletekre és hipotézisekre támaszkodó kutatások nem térnek ki részletesebben, hiszen ezek elsődleges célja az, hogy a túlnyomó többséget kitevő normál esetekre adjanak valamilyen magyarázatot. Mivel a társadalomtudományi törvények jellegüknél fogva nem lehetnek univerzálisak, általában a nagy esetszámmal dolgozó kutatások nem törvényszerűségekről, hanem valószínűségekről beszélnek. A deviáns eset magyarázata így az esettanulmányokra marad, azon belül pedig a módszertani szakirodalom szerint a folyamatkövetés módszere kínálkozik a legjobb stratégiának..$^{28}$ Ráadásul az ilyen folyamatkövetésre épülő

25 Brandon L. Bartels - Christopher D. Johnston: On the Ideological Foundations of Supreme Court Legitimacy in the American Public. American Journal of Political Science, 57. (2013), 1. 184-199.

26 Ugyanakkor arra is felhívják a figyelmet, hogy kevésbé polarizált országokban, így pl. Németországban ez a fajta viszonyulás a bíróságokhoz kevésbé meghatározó [Driscoll-Nelson i. m. (15. lj.) 31.].

27 Alexander L. George - Andrew Bennett: Case Studies and Theory Development in the Social Sciences. Cambridge, MIT, 2005. 215.

28 Andrew Bennett - Jeffrey T. Checkel (szerk.): Process Tracing: From Metaphor to Analytic Tool. Strategies for Social Inquiry. Cambridge, Cambridge University Press, 2014. 13. 
esettanulmányok az általános elméletek módosításaihoz is hozzájárulhatnak, a nagy esetszámmal dolgozó kutatások elméleti keretének a finomításához vagy kontingens általánosításokhoz vezethetnek, amelyek tisztázhatják, hogy milyen feltételek megléte esetén várható az események más jellegü kimenetele. ${ }^{29}$

\section{A vizsgált eset és történelmi kontextusa}

A Kruzifix-ügy történelmi kontextusához tartozik, hogy az 1946-ban elfogadott bajor alkotmány az iskolákban elérendő legfőbb képzési célok között első helyen említi az Isten iránti alázatosságot, ${ }^{30}$ miközben kétféle közoktatási intézményről tesz említést: egyrészt a keresztény felekezeti iskolákról (Bekenntnisschule), másrészt pedig „keresztény közösségi iskolákról” (Gemeinschaftsschulen), tulajdonképpen ökumenikus iskolákról. Ez utóbbiak létesítése azonban inkább a kivételt jelentette, és alapításuk gyakran komolyabb adminisztratív akadályokba ütközött, azaz a mélyen katolikus Bajorországban 1945 után a bajor tanulók java része keresztény felekezeti (elsősorban katolikus) iskolákba járt. ${ }^{31}$

A 60-as évek közepére aztán megerősödtek azok a hangok, amelyek idejétmúltnak vélték a felekezeti köziskolákat, és a „közösségi iskolák” (Gemeinschaftsschule) egyenjogúsítását követelték. ${ }^{32} \mathrm{~A}$ keresztényszocialisták (CSU) által vezetett bajor kormány alkotmánymódosító javaslata (elébe menvén a szociáldemokraták és a liberálisok követeléseinek) megszüntette a különbséget a felekezeti és az ökumenikus iskolák között, ugyanakkor expliciten beleírta az alkotmánymódosítás révén az alkotmányba, hogy minden iskolában a keresztény tanítás alapján nevelik a tanulókat. Ebbe a kompromisszumos megoldásba egyébként a szociáldemokraták is belementek (ahogy az 1946-os alkotmány esetében is), így aztán a bajor alkotmány 1968-as módosítását követően, amelyet egyébként egy népszavazáson is jóváhagytak, ${ }^{33}$ az alkotmány 135. cikke kimondta, hogy Bajorország minden közoktatási intézményében a tanulókat a keresztény vallásfelekezetek alapelvei szerint tanítják és nevelik, aminek részleteiről az 1983-ban módosított közoktatási törvény rendelkezett. ${ }^{34}$

29 David Collier: Understanding Process Tracing. Political Science E Politics, 44. (2011), 4. 823-830. 824.

30 Verfassung des Freistaates Bayern vom 2. Dezember 1946. Art. 131, 2): „Oberste Bildungsziele sind Ehrfurcht vor Gott..."

31 A szociáldemokraták (SPD) ugyan a közösségi iskolák mellett érveltek, ám belátván azt, hogy a mélyen katolikus Bajorországban milyen hagyományai vannak a felekezeti iskoláknak, illetve figyelembe véve azt a tényt, hogy a CSU-nak egymagában is majdnem kétharmados többsége volt a bajor alkotmányozó gyűlésben, végül lemondtak erről [Fritz Schäffer: Bekenntnisschule (2006). Elérhető: www.historisches-lexikon-bayerns.de/Lexikon/Bekenntnisschule (A letöltés dátuma: 2020. 10. 06.)].

32 Fritz Schäffer: Gemeinschaftsschule (2006). Elérhető: www.historisches-lexikon-bayerns.de/ Lexikon/Gemeinschaftsschule (A letöltés dátuma: 2020. 10. 06.)

33 40,7 százalékos részvétel mellett a résztvevők 76,3 százaléka értett egyet az alkotmánymódosítással [Otmar Jung: Volksabstimmungen (2006). Elérhető: www.historisches-lexikon-bayerns.de/Lexikon/ Volksabstimmungen\#17 (A letöltés dátuma: 2020. 10. 06.)].

34. Verfassung des Freistaates Bayern vom 2. Dezember 1946. Art. 135. 
Ennek a közoktatási törvénynek a 13. paragrafusa írta elő a bajor alkotmány fent említett 135. cikkére hivatkozva azt, hogy a bajor állami közoktatási intézményekben kötelező kifüggeszteni a keresztet. Bajor szempontból nézve tehát alapvetően minden a legnagyobb rendben volt: a bajor állam alkotmánya írta elő azt a kötelezettséget, hogy a keresztény alapelvek alapján kell tanítani az állami iskolákban, ennek pedig egyik megvalósulási formáját biztosította az 1968-ban elfogadott és 1983-ban módosított közoktatási törvény, amely előírta a feszület kifüggesztését a tanterem falán. De akkor miért is vált konfliktus forrásává ez a rendelkezés?

A BVerfG Kruzifix-döntéséhez vezető folyamat még a 80-as évek közepére nyúlik vissza. ${ }^{35}$ Három bajor testvér szülei sérelmezték 1986-ban, hogy gyermekeiket a család világnézetével nem egyező behatás éri az iskolában, ráadásul elkerülni sem tudják ezt a behatást, hiszen minden közoktatási intézmény tantermének falán ott lóg a kereszt. A szülők, akik Rudolf Steiner nézeteit magukénak vallva az antropozófiai irányzat hívei voltak, előbb a reutingi helyi iskola vezetőinél próbálták meg elérni azt, hogy a kereszt lekerüljön a tanterem faláról, ám nem jártak sikerrel annak ellenére, hogy kompromisszumos megoldások is körvonalazódtak az ügyben (feszület helyett egy kisebb keresztet helyeztek az ajtó fölé). Ráadásul kisebb gyermekeik beiskolázásakor ismételten fellángolt a vita az iskola és a szülők között, a szülők pedig immáron azt követelték, hogy minden osztályterem faláról és a folyosókról is kerüljön le a feszület, mivel gyermekeik ott is szembesülhetnek azzal. Bár átmenetileg egy Waldorf-iskolába is beadták a gyerekeiket, a magániskolát nem tudták finanszírozni, így aztán 1991-ben a bajor közigazgatási bíróságra (Bayerischer Verwaltungsgerichtshof) vitték az ügyet, azt követelvén, hogy minden olyan helyiségből, amelyekben gyerekeiknek a tankötelezettség miatt meg kell jelenniük, vegyék le a keresztet. A bajor közigazgatási bíróság elutasította a keresetet, a szülők pedig a német szövetségi alkotmánybírósághoz fordultak azzal az indítvánnyal, hogy a bíróság semmisítse meg a bajor közigazgatási bíróság döntését, illetve magát a bírósági döntés alapjául szolgáló közoktatási törvény vonatkozó passzusát is, mivel azok a szabad vallásgyakorlásnak a német alaptörvény (Grundgesetz) 4. cikk 1. bekezdésében rögzített alapvető jogát sértik.

A BVerfG 1995. május 16-án kelt döntésében (1 BvR 1087/91) helyt adott az indítványnak, és nemcsak a bajor közigazgatási bíróság döntését, hanem az annak alapjául szolgáló törvény vonatkozó részét is megsemmisítette mondván, hogy az a „negatív vallásszabadság" alapvető jogába ütközik. A negatív vallásszabadság fogalma alatt azt értette a bíróság, hogy az állam polgárainak ne kelljen kötelezően olyan vallási tanokkal „szembesülniük”, amelyekkel nem értenek egyet. Az érdekes módon csak augusztus 10-én nyilvánosságra hozott döntés értelmében tehát le kellett (volna) venni a bajor állami iskolák tantermeinek faláról a keresztet, csakhogy erre a gyakorlatban (néhány kivételes esettől eltekintve) soha nem került sor. A kereszt mind a mai napig ott lóg a bajor állami közoktatási intézmények tantermeinek falán, sőt 2018. június 1-je óta immáron nemcsak a tantermekben, hanem minden bajor állami hivatal

35 Az ügy részleteiről ld. a Bundesverfassungsgericht döntését: 1 BvR 1087/91. 
bejáratánál is ki kell függeszteni őket. Markus Söder bajor miniszterelnök ugyanis a 2018-as októberi bajor parlamenti választások nyitányaként 2018 áprilisában olyan kormányrendeletet fogadtatott el, amely szerint a bajor állami hivatalokban is ki kell helyezni a falra a keresztet. Persze Bajorországban már addig is igen sok helyen ki voltak függesztve (sokszor középületekben is) a feszületek, ráadásul Söder saját bevallása szerint sem ellenőrizték módszeresen, hogy végrehajtják-e a kormányrendeletet. ${ }^{36}$

A 2018-as feszületügy leglényegesebb pontja ugyanakkor megegyezik az 1995-ös ügy legfontosabb kérdésével. A kérdés ugyanis akörül forgott mindkét alkalommal, hogy vajon a feszület elsősorban vallási, vagy önálló életre kelt kulturális, civilizációs szimbólum-e. A Söder-kormány, okulva az 1995-ös alkotmánybírósági határozat körüli polémiából és persze az Emberi Jogok Európai Bírósága (EJEB) második Lautsi-döntéséből, ${ }^{37}$ már kifejezetten Bajorország kulturális és történelmi sajátosságaként (als Ausdruck der geschichtlichen und kulturellen Prägung Bayerns) hivatkozott a keresztre a vonatkozó kormányrendeletben - a vallási dimenzió a hivatalos dokumentumban meg sem jelenik. ${ }^{38} \mathrm{~A}$ bajor miniszterelnök pedig nyilatkozataiban még egyértelműbbé tette, hogy a kereszt nemcsak a kereszténység legfőbb szimbóluma, hanem olyan kulturális jelkép, amely a nyugati kultúrkörre utal: „A kereszt a kulturális identitás alapvető szimbóluma." ${ }^{39} \mathrm{Ez}$ az érv tehát, hogy a kereszt nem kizárólag vagy elsősorban vallási, hanem kulturális szimbólum, már a Kruzifix-vitában is nagy jelentőséggel bírt, ám 1995-ben a német alkotmánybíróság végül a keresztre elsősorban mint vallási jelképre tekintett. A vallási jelképek kötelező kifüggesztése az állami iskolákban pedig nem egyeztethető össze az állam semlegességének az elvével, illetve sérti az egyén számára a német alaptörvény 4 . cikke által garantált (negatív) vallásszabadság jogát, éppen ezért minden állami iskola tantermének a faláról el kell távolítani a keresztet - szólt a BVerfG verdiktje 1995-ben.

36 Söder ist offen für Kritik am „Kreuzerlass”. Domradio, 2019. április 20. Elérhető: www.domradio.de/ themen/kirche-und-politik/2019-04-20/wir-haben-das-sehr-liberal-gehandhabt-soeder-ist-offenfuer-kritik-am-kreuzerlass (A letöltés dátuma: 2020. 10. 05.)

37 A feszület mint kulturális vagy vallási szimbólum értelmezése más európai országokban is szült már komolyabb feszültségeket, az európai színtéren pedig az EJEB 2009-es és 2011-es ún. Lautsidöntései járultak hozzá a feszületkérdés jogi tisztázásához (vagy éppen a kérdés még vitatottabbá válásához). A jelen dolgozat azonban nem jogdogmatikai elemzésre vállalkozik, ahhoz 1. Koltay András: Európa és a feszület jele: a Lautsi and Others v. Italy ügy alapvető kérdéseiről. In Tattay Levente - Pogácsás Anett - Molnár Sarolta (szerk.): Pro vita et scientia. Ünnepi kötet Jobbágyi Gábor 65. születésnapja alkalmából. Budapest, Szent István Társulat, 2012; Schanda Balázs - Koltay András: A Lautsi-ügy a feszületről az állami iskola osztálytermében: a vallási jelképek használatának megengedettsége a semleges állam közéletében. Jogesetek Magyarázata, 2. (2011), 4. 77-85.

38 Allgemeine Geschäftsordnung für die Behörden des Freistaates Bayern (AGO) vom 12 Dezember 2000 (GVBl. S. 873; 2001 S. 28) BayRS 200-21-I (\$\$ 1-38) - Bürgerservice, 28. paragrafus.

39 Markus Söder : Bayern schreibt Kreuze in allen Staatsbehörden vor. Die Zeit, 2018. április 24. Elérhető: www.zeit.de/gesellschaft/zeitgeschehen/2018-04/markus-soeder-csu-kreuz-christentumbehoerden-bayern (A letöltés dátuma: 2020. 10. 06.) 


\section{A válaszreakció: fenyegetések, petíciók, tüntetések és törvénymódosítás}

A BVerfG 1995-ös döntése óta sok víz folyt le a Dunán, a feszület és a kereszténység ügye pedig az európai színteret is elérte, előbb az európai alkotmány vitája kapcsán, aztán pedig az (EJEB) ítéletei (1. és 2. Lautsi-ügy) kapcsán. Ma úgy tủnik, hogy jogi vagy jogdogmatikai szempontból valamelyest nyugvópontra jutott a vita, amelynek egyik kezdőpontja a BVerfG Kruzifix-döntése volt. ${ }^{40}$ A jogi vagy jogdogmatikai viták elcsendesülése és maguk a bírósági döntések azonban nem mindig jelentik egy ügy végső lezárását. Nemcsak arról van szó, hogy évtizedekkel később megváltozhat a bíróságok véleménye, hanem arról is, hogy közvetlenül a döntés nyilvánosságra hozatalát követően miként reagálnak a felek, a politikai szereplők vagy éppen az érintett társadalmi csoportok a bíróság döntésére. Az első Lautsi-döntés kapcsán például a vesztes olasz állam fellebbezett, sőt még az olasz társadalom bizonyos csoportjai is elégedetlenségüknek adtak hangot, ugyanakkor az olasz vagy európai közvélemény radikális mobilizálásáról azért egészen biztosan nem beszélhetünk. ${ }^{41}$ Az EJEB második Lautsi-döntését követően pedig mintha elültek volna a hullámok, és a feszület ügye nemcsak a jogászok és az érintett felek között, hanem az európai színtéren és az európai társadalmakban is nyugvópontra jutott.

Nem ez volt a helyzet azonban a BVerfG 1995-ös Kruzifix-döntését követően. Bár a tantermek falára kihelyezett kereszt ügye a német szövetségi alkotmánybíróság döntését megelőzően (egészen pontosan a döntés nyilvánosságra hozatalát megelőzően) egyáltalán nem volt témája a német közbeszédnek, ${ }^{42} 1995$. augusztus 10-én, amikor végül nyilvánosságra hozták a döntést, minden egy csapásra változott meg.

„Die Kreuze bleiben” („A keresztek a helyükön maradnak”) - nyilatkozta Edmund Stoiber, Bajorország akkori miniszterelnöke pár nappal azt követően, hogy a BVerfG 1995. augusztus 10-én nyilvánosságra hozta az azóta híressé vált Kruzifix-döntését. A bajor kormányzó párt, a CSU müncheni tagszervezetének elnöke, Peter Gauweiler, ha nem is ennyire egyértelműen, de elég nyilvánvalóan arra utalt, hogy a bíróság döntése pusztába kiáltott szó maradhat: „A politikai bátorságunk fokmérője lesz, hogy a bírósági döntést valóban végrehajtjuk-e." Hans Maier, egykori bajor kultuszminiszter ennél egyértelmúbb volt, amikor kijelentette, hogy „a legfelső bírói fórum ilyen esztelenségével és önteltségével szemben nemcsak megengedett, hanem egyenesen kötelező az ellenállás". Theo Waigel, a CSU elnöke, nem mellékesen pedig Helmut Kohl kancellár pénzügyminisztere (1988-1998), homályosabban ugyan, de azért elég

40 Az EJEB ítélkező kamarája előbb 2009-ben a BVerfG 1995-ös döntéséhez hasonló ítéletet hozott a Lautsi-ügyben, majd ezt a döntést a Nagykamara 2011-ben felülvizsgálta, és azt állapította meg, hogy nem sérti a negatív vallásszabadság alapvető jogát az, ha az olasz közoktatási intézmények falán ott lóg a kereszt. Az ügy jogi elemzéséhez ld. Schanda-Koltay i. m. (38. lj.).

41 Dominic McGoldrick: Religion in the European Public Square and in European Public Life: Crucifixes in the Classroom? Human Rights Law Review, 11. (2011), 3. 451-502. 470.

42 Gary S. Schaal: Crisis! What Crisis? Der „Kruzifix-Beschluss” und seine Folgen. In Robert C. van Ooyen - Martin H. W. Möllers (szerk.): Das Bundesverfassungsgericht im politischen System. Wiesbaden, VS Verlag für Sozialwissenschaften, 2015. 175. 
sokat sejtetően arra utalt, hogy ennek a döntésnek akár az is lehet a következménye, hogy radikálisan átalakítják a BVerfG müködését. ${ }^{43}$ Friedrich Wetter müncheni bíboros a náci rezsim időszakát idézte fel a bírósági döntés kapcsán: a bíboros szerint a nácik távolították el utoljára a keresztet az iskolai tantermek faláról, ennek megfelelően ugyanúgy kell eljárni, mint a nácikkal szemben, azaz ellen kell állni a döntés végrehajtását illetően. ${ }^{44} \mathrm{~A}$ bajor tartományi parlament keresztényszocialista (CSU) képviselője, Sepp Ranner pedig egyenesen veréssel fenyegette meg a bírókat: „A bírók és a panaszosok maguk jöjjenek ide, és vegyék le ők a kereszteket a tantermek faláról! Mi, parasztok, mindenesetre cséphadaróval fogjuk várni őket." ${ }^{45}$

A nyilvános elégedetlenség nem korlátozódott Bajorországra: Joachim Hörster, a szövetségi törvényhozás (Bundestag) CDU-CSU közös frakciójának ügyvezetője vitát kezdeményezett arról, hogy a többség miként védhető meg a kisebbség zsarnokságával szemben, Rupert Scholz, a CDU-CSU-frakció frakcióvezető-helyettese pedig kijelentette, hogy a „szövetségi alkotmánybíróság nem a köztársaság pápája”, miközben néhányan azon tréfálkoztak, hogy a keresztek helyére a bírókat kellene felakasztani. ${ }^{46}$ Halálos fenyegetések is érkeztek a bírókhoz, Dieter Grimm alkotmánybírótól pedig azt kérdezték amerikai kollégái, hogy a német kancellárnak akkor most tényleg csapatokat kell-e küldenie Bajorországba, hogy végrehajtsák a BVerfG döntését - utalva ezzel Dwight D. Eisenhower elnökre, aki szövetségi csapatokat küldött Arkansasba, hogy ott végrehajtsák az amerikai Legfelsőbb Bíróság Brown v. Board of Education-döntését. ${ }^{47}$

Az érintett politikusok, közszereplők és katolikus hívek elégedetlenségüknek és felháborodásuknak nemcsak szóban adtak hangot, hanem írásban is: több mint 250 ezer aláírást gyűjtöttek és juttattak el a karlsruhei bírókhoz, a Bild napilap pedig egy olyan telefonvonalat is létrehozott, ahol a bíróság döntésével szembeni elégedetlenségüknek is hangot adhattak a bajorok, de sokan egyenesen a karlsruhei bíróságot hívták inkább. A Süddeutsche Zeitung beszámolója szerint égtek a vonalak és a faxgépek Karlsruhéban, de a portásoknak is akadt elég dolguk az elégedetlenségüket személyesen kifejezni akarókkal. ${ }^{48} \mathrm{Ha}$ ez nem lett volna elég, akkor alig egy hónappal később az utca népe is megtapasztalhatta (legalábbis Münchenben), hogy milyen indulatokat váltott ki a BVerfG döntése: 1995. szeptember 23-án a müncheni Odeonsplatz megtelt emberekkel: 25 ezren tüntettek a bíróság döntése ellen.

43 Rolf Lamprecht: Das Bundesverfassungsgericht. Geschichte und Entwicklung. Bonn, Bundeszentrale für politische Bildung, 2011. 246.

44. Uwe Wesel: Der Gang nach Karlsruhe. Das Bundesverfassungsgericht in der Geschichte der Bundesrepublik. München, Karl Blessing, 2004. 317.

45 Das Kreuz ist der Nerv. Der Spiegel, 1995. augusztus 14. Elérhető: www.spiegel.de/spiegel/print/d-9206287.html (A letöltés dátuma: 2020. 10. 06.)

46 Justin Collings: Democracy's Guardians: A History of the German Federal Constitutional Court, 1951-2001. Oxford, Oxford University Press, 2015. 263.

47 Uo. 264.

48 Wesel i. m. (44. lj.) 318. 
A Német Szövetségi Köztársaság történetében még soha nem keltett életre egy bírósági döntés ekkora tömegmozgalmat. Stoiber regnáló bajor miniszterelnök arról beszélt a tüntetésen, hogy bizonyos esetekben a kisebbségnek is toleránsnak kell lennie a többséggel szemben. „Respektáljuk a bíróság döntését, de tartalmilag nem fogadjuk el azt" - tette hozzá, és szónoklatát azzal zárta, amit már a döntés nyilvánosságra hozatalának másnapján adott interjújában is hangsúlyozott: „A keresztek a helyükön maradnak." Wetter bíboros az 1598-as nantes-i ediktumra utalva „intoleranciaediktumról" beszélt a tömegnek a Kruzifix-döntés kapcsán, és ismételten a náci diktatúrával való párhuzamra utalt. ${ }^{49}$

A helyi újságok kommentátorai, sőt az országos napilapok véleménycikkei, de az alkotmányjogi szakkommentátorok java része is elégedetlenségét fejezete ki. ${ }^{50}$ Az országos napilapokban zajló diskurzus elemzése azt is kimutatta, hogy a véleménycikkek túlnyomó többsége nem fogadta el a BVerfG állami semlegességre vonatkozó érvelését, és sokkal inkább arra fókuszáltak, hogy Németország egy keresztény alapokon álló politikai közösség. ${ }^{51} \mathrm{~A}$ BVerfG érvelése mellett csak a véleménycikkek kisebbsége tört lándzsát, ráadásul a cikkek 40 százalékában finoman vagy kevésbé kifinomult formában amellett érveltek, hogy a bírósági döntést figyelmen kívül lehet hagyni. Ez utóbbi azért problematikus, mert immáron nemcsak a szimbolikus, hanem az instrumentális dimenzióban is kénytelen volt a BVerfG komoly veszteségeket elszenvedni. Másként fogalmazva: megnőtt az esély arra, hogy a nyílt bírálat mellett az engedetlenség is szélesebb körben elterjedhet - legalábbis a Kruzifix-döntés kapcsán. $^{52}$

Az újságok véleménycikkei alapvetően negatív tónusúak voltak, csak az 1970-es évek végén jelent meg annyi negatív hangvételű cikk a szövetségi alkotmánybíróságról, mint 1995-ben. ${ }^{53}$ Ráadásul a közvélemény-kutatási adatok is azt mutatták, hogy a megkérdezettek több mint fele egyértelmüen rossz döntésnek tartotta a BVerfG döntését, és mindössze 22 százalékuk tartotta helyesnek. ${ }^{54} \mathrm{~A}$ közvéleménynek a szövetségi alkotmánybíróságról alkotott általános képe is jelentősen átalakult: míg korábban a németek fele jó véleménnyel volt a szövetségi alkotmánybíróságról, 1995-ben csak 36 százalékuk, de a BVerfG általános bizalmi indexe is 40 százalékra esett, miközben a 80-as években még bőven 50 százalék fölött járt. ${ }^{55}$

A feszültség tehát tapintható volt, a tüntetést és a tiltakozáshullámot követően az ősz nagy kérdése az maradt, hogy mit lép a bajor törvényhozás. A bajor törvény-

49 Barbara Supp: Heiliger Edmund, bitt' für uns. Der Spiegel, 1995. október 2. Elérhető: www.spiegel. de/spiegel/print/d-9223884.html (A letöltés dátuma: 2020. 10. 06.)

50 Schaal i. m. (42. lj.) 271; Collings i. m. (46. lj.) 264.

51 Schaal i. m. (42. lj.) 272.

52 Uo. 274.

53 Oliver Lembcke: Über das Ansehen des Bundesverfassungsgerichts: Ansichten und Meinungen in der Öffentlichkeit 1951-2001. Berlin, Berliner Wissenschafts, 2006. 47.

$54 \quad$ Schaal i. m. (42. lj.) 271.

55 Hans Vorländer - Gary S. Schaal: Integration durch Institutionenvertrauen? In Hans Vorländer (szerk.): Integration durch Verfassung. Wiesbaden, VS Verlag für Sozialwissenschaften, 2002. 357. 
hozók két nappal karácsony előtt, 1995. december 23-án fogadták el a vonatkozó közoktatási törvény módosítását, amellyel végeredményben elérték, hogy a keresztek a helyükön maradjanak, és csak nagyon kivételes esetben szedjék le őket a tantermek faláról. Miközben a BVerfG döntése még arról szólt, hogy a bajor állami közoktatási intézmények falán sehol sem lehet kifüggesztve kereszt, addig a valóság egészen más képet mutatott. A törvénymódosítás mindössze két ponton hozott változást: egyrészt a módosított törvény a keresztről immáron expliciten is azt állította, hogy az Bajorország történelmi és kulturális sajátosságaihoz tartozik, és ezért kell kifüggeszteni minden osztályterembe, azaz a kereszt vallási dimenziója háttérbe szorult. ${ }^{56}$ A második mondatban utaltak arra, hogy a bajor alkotmányban rögzített legfőbb képzési célokat a keresztény és a nyugati értékek alapján a vallásszabadság megőrzése mellett kell megvalósítani, de az igazán izgalmas kiegészítés a harmadik mondatban rejlett: amennyiben ugyanis egy érintett szülő kifogásolná azt, hogy az osztálytermek falán egy feszület lóg, akkor az iskola vezetőjéhez fordulhat, de csak abban az esetben, ha komoly és elfogadható indokot tud felhozni arra nézvést, hogy vallását vagy világnézetét sérti a kereszt. Ebben az esetben az iskolai vezet” „megkísérli” (versucht) a helyzetet rendezni. Amennyiben nem sikerülne egyezségre jutni az érintett szülővel, az iskola vezetője jogosult az egyedi eset vonatkozásában olyan megoldást érvényre juttatni, amely az érintett szülő gyerekének vallásszabadságát és világnézetét tiszteletben tartja, ám egyben az osztálytársak vallási meggyőződését is figyelembe veszi. Ráadásul a „többség akaratát is figyelembe kell venni, amennyire csak lehet” (dabei ist auch der Wille der Mehrheit soweit möglich zu berücksichtigen) - szól a módosított törvény szövege. Ennek a törvénymódosításnak köszönhetően a kereszt kint maradt az osztálytermek falán, ha pedig ez valamely szülőnek nem tetszett, akkor az iskola vezetője volt illetékes a konfliktust elrendezni.

Természetesen a bajor közoktatási törvény ezen módosított változatát is megtámadták bíróság előtt, amiről először a bajor alkotmánybíróság (Bayerischer Verfassungsgerichtshof) döntött: 1997. augusztus 1-jei határozatában a bajor alkotmánybíróság kimondta, hogy konfliktus esetén az érintett szülő kérésének a többség akarata ellenére is eleget kell tenni, amennyiben komoly és belátható indokkal arra a következtetésre lehet jutni, hogy túlzott mértékben terheli az érintett felet a kereszt látványa. ${ }^{57}$ Hogy a komoly és belátható indok mit is jelent, az persze ismételten csak az iskolai vezetőre van bízva. Éppen ezért került az ügy ismételten a BVerfG elé, csakhogy a német szövetségi alkotmánybíróság első szenátusának 1. kamarája formális okokból visszautasította, hogy érdemben tárgyalják a beadványt, mivel nem tartotta alkotmányjogi értelemben alapvető fontosságúnak az ügyet. Ugyanakkor a bírák utaltak arra is, hogy a (bajor) törvényhozónak nagy mozgástere van abban, hogy hogyan próbálja meg a negatív és pozitív vallásszabadság közötti konfliktusokat elrendezni, márpedig a bajor törvényhozás a törvénymódosítással eleget tett annak a kötelezett-

56 Bayerisches Gesetze über das Erziehungs und Unterrichtswesen vom 23. Dezember 1995.

57 Entscheidung des Bayerischen Verfassungsgerichtshofs vom 1 August 1997 - Vf. 6-VII-96. 
ségnek, hogy szabályozza a konfliktusok feloldását. ${ }^{58}$ Hogy jogdogmatikai értelemben helytálló volt-e ez a visszautasítás, abba természetesen nem mennénk bele, hiszen a jelen tanulmány célja nem a bírósági döntések helyességének a vizsgálata, hanem a Kruzifix-döntéshez vezető okok feltárása. Az ugyanakkor bizonyos, hogy a BVerfG az 1995-ös döntéséhez képest szinte teljes hátraarcot mutatott ezzel az új, visszautasító határozatával, hiszen érdemben nem is vizsgálta a panaszokat, miközben jelezte, hogy a törvényhozás felelőssége a pozitív és negatív vallásszabadság összeütközésének rendezése. Mindezekből kifolyólag immáron egyáltalán nem ragaszkodott ahhoz, hogy az állami fenntartású iskolák faláról lekerüljenek a keresztek. ${ }^{59}$

\section{A bírósági döntés (nem) teljesülése és a hipotézisek cáfolata}

\subsection{A birósági döntés (nem) teljesülése}

Az első kérdés, amit az 1995-ös Kruzifix-ügy kapcsán érdemes feltennünk, az a BVerfG döntésének teljesülésére vonatkozik. Kétségkívül igaz, hogy a bajor törvényhozás módosított a közoktatási törvényen, és lehetővé tette azt, hogy konfliktus esetén legalább minimálisan legyen meg a lehetőség a konfliktus rendezésére. Persze az nagy kérdés, hogy az iskolai vezetők kezébe adott „jogorvoslati” lehetőség kiállja-e valójában a jogorvoslathoz való jog próbáját - minden bizonnyal súlyos kétségek merülhetnek fel ezzel kapcsolatban. Mindenesetre az bizonyos, hogy az alapjogok védelmében amúgy élenjáró BVerfG 1997-ben már nem látott semmi kivetnivalót a módosított közoktatási törvényben. Hogy milyen mértékben befolyásolta a Német Szövetségi Alkotmánybíróság 1997-es döntését az a tiltakozáshullám, amely az 1995-ös döntést kísérte, az persze nagyon nehezen állapítható meg, de minden bizonnyal jóval szigorúbb (és következetesebb) lett volna a második döntésében, ha nem kellett volna szembesülnie a tiltakozás fent vázolt formáival 1995 folyamán.

Annyi bizonyos, hogy a BVerfG 1995-ös döntése nemcsak explicite mondta ki azt, hogy állami iskolákban sehol nem lóghat kereszt a tantermek falán, hanem az indokolás szellemisége is egyértelművé tette, hogy a BVerfG szerint nem lehet olyan hely Németországban, ahol feszülettel kell szembesülniük a tanulóknak az állami fenntartású iskolák falai között. A szándék és a cél egyértelmű volt: a keresztek nem lóghatnak állami iskolák falain. Ha innen olvassuk a BVerfG döntését, akkor az is egyértelmủ, hogy az alkotmánybíróság rendelkezése és az 1995-ös döntés szellemisége

58 Beschluss der 1. Kammer des Ersten Senats vom 27 Oktober 1997 - 1 BvR 1604/97.

59 Egyetlen fejleményt érdemes még megemlíteni a döntés utótörténetét illetően: egyedi esetet vizsgálva a szövetségi közigazgatási bíróság (Bundesverwaltungsgericht) 1999-ben arra jutott, hogy a módosított bajor közoktatási törvényt alkotmánykonform módon úgy kell értelmezni, hogy komoly és belátható indokként kezelhető egyszerüen az a tény, ha a szülők kijelentik, hogy ateisták, vagy éppen vallásellenes nézeteik vannak (BVerwG 6 C 18.98). Ugyanakkor mivel a szövetségi közigazgatási bíróság csak egyedi esetben döntött, azaz nem volt erga omnes hatálya döntésének, a keresztek tulajdonképpen csak olyan egyedi esetekben kerültek le a bajor közoktatási intézmények faláról, amikor a szülők bíróságra vitték az ügyet, és ott nyertek. 
egyáltalán nem valósult meg - vagy még erősebben fogalmazva, éppen annak ellenkezője valósult meg.

A bírósági döntések teljesülésének, a teljesülés fogalmának, illetve mérhetőségének széles körű nemzetközi szakirodalma van - bár az is igaz, hogy a konceptualizáció és a mérhetőség problémája azért igen komoly kérdéseket vet fel. Diana Kapiszewski szerint egy bírósági döntés akkor teljesül, ha az érintett szereplők végrehajtják azt a cselekményt (vagy éppen tartózkodnak azon cselekmény megtételétől), amelyet a bíróság írt elő (vagy tiltott meg) számukra a döntésében. ${ }^{60} \mathrm{~A}$ teljesülés tehát az érintett szereplők viselkedésére, a jogszabályok megváltoztatására és ezáltal (jó esetben) a tényállásra van hatással. Természetesen sokszor csak részlegesen teljesülnek a bírósági döntések, ebből kifolyólag azok teljesülését valamilyen skálán kellene elhelyezni. Ráadásul azt is figyelembe kell venni, hogy az érintett szereplők adott körülmények között felülírhatják a bíróság döntését vagy éppen retorziókkal élhetnek a bírósággal szemben egy-egy döntés ürügyén.

Az általunk közelebbről megvizsgált eset kapcsán mindenesetre megállapítható, hogy az eredeti döntés nem a jogorvoslati lehetőség hiánya miatt állapította meg a bajor közoktatási törvény alkotmányellenességét, hanem mivel azt a Grundgesetz 4. cikk 1. bekezdésével, azaz a (negatív) vallásszabadság alapjogával ellentétesnek ítélte. Azaz nem a jogorvoslati eljárás lehetőségét hiányolta a bíróság, hanem a negatív vallásszabadság teljes körű biztosítását próbálta meg garantálni a döntésében, ennek eszköze pedig a kereszt levétele lett volna, nem pedig egy gyenge lábakon álló konfliktusfeloldó eljárás bevezetése. Ennek fényében a Kruzifix-döntés kapcsán egészen biztosan állíthatjuk, hogy annak a bizonyos skálának az egyik végpontján (nem teljesülés) elhelyezkedő esetről van szó. A Kruzifix-döntés (általános érvényüen, kivételt nem megengedve) ugyanis arról szólt, hogy le kell venni a keresztet az állami iskolák faláról. Tényszerủen viszont ez soha (vagy csak nagyon kivételes esetekben) valósult meg. Hogy pontosan mi lehetett az oka annak, hogy „elszabotálták” a döntés végrehajtását, arra egyrészt az elméleti szakirodalom feltevéseire, másrészt a folyamatkövetés módszerére támaszkodva kísérlünk meg választ adni az alábbiakban.

\subsection{Az elméletre alapozott hipotézisek cáfolata}

Az elméletre alapozott hipotézisek kapcsán jól látható, hogy az 1., az 1.1. és a 2. hipotézis egyáltalán nem állta meg a helyét a Kruzifix-ügy kapcsán. Egyrészt a BVerfG a közvélemény túlnyomó többségének véleményével és a magas társadalmi támogatottsággal rendelkező politikai erővel (CSU) erőteljesen szembement, amikor elrendelte az iskolai keresztek levételét, ezzel pedig azt kockáztatta, hogy a társadalmi támogatottsága jelentősen csökken, ami a politikai szereplőkkel szembeni mozgásterét jelentősen korlátozhatta volna (az 1. és az 1.1. hipotézisek cáfolata). Másrészt a bajor kormány a nagy társadalmi támogatottsággal bíró BVerfG döntésének végrehajtását

60 Kapiszewski-Taylor i. m. (5. lj.) 805. 
egészen egyszerűen elszabotálta, noha a Német Szövetségi Alkotmánybíróság folyamatosan magas diffúz társadalmi támogatottsággal bírt, és a médiaelemzések is arra utaltak, hogy döntéseit a német közvélemény folyamatosan figyelemmel kísérte. ${ }^{61}$ A racionális döntéselméleti modell alapján ez azzal a veszéllyel járhatott volna a bajor kormány számára, hogy a választók megbüntetik. Ennek ellenére a bajor parlamenti többség a BVerfG döntésének elszabotálását választotta (a 2. hipotézis cáfolata). A szoros pártkötődés ugyan némileg magyarázhatja azt, hogy a Kruzifix-döntéssel szemben az engedetlenséget választották a bajor törvényhozók (a 2.1. hipotézis), ugyanakkor összességében mégiscsak úgy tűnik, hogy a racionális döntéselméleti szakirodalom alapján felállított hipotézisek nem bírnak kellő magyarázó erővel a Kruzifix-döntés kapcsán.

\section{A deviáns eset magyarázata}

\subsection{Miért viselkedett deviáns módon a bíróság?}

Mi lehet az oka annak, hogy sem az első hipotézis, sem pedig a második hipotézis állításai nem igazolódtak be? Miért nem a társadalom többségének a véleményével megegyező döntést hoztak a bírók, ha egyszer ez lett volna stratégiai értelemben racionális a részükről? És miért ment nyíltan szembe a bajor kormány a BVerfG döntésével, ha egyszer a racionális döntéselméleti modell alapján azt lehetett volna várni, hogy a bajor parlamenti többség deferens módon fog viselkedni? Egyszerủbben fogalmazva: mi lehetett az oka annak, hogy a stratégiai/racionális döntéselméleti magyarázó modellek nem igazolódtak be sem a BVerfG, sem a bajor kormány vonatkozásában? Miért nem teljesült végül a BVerfG döntése? A válasz kellőképpen összetett mindkét esetben, így érdemes alaposabban is körbejárni az ügyet.

Ami az első hipotézist illeti, a körülmények alapos vizsgálata és a bírók nyilatkozatai alapján egyértelműnek tủnik, hogy a bírók ezen ügy kapcsán egyáltalán nem stratégiailag gondolkodtak, nem vették tudatosan számba a döntés esetleges társadalmi, politikai következményeit, sőt egyáltalán nem tudatosult bennük, hogy a kérdés súlyos konfliktust generálhat. A politikai szereplők és az érintettek esetleges válaszreakcióit egyáltalán nem vették számba, nem fontolták meg, hogy a döntés a bajor választók többségében vagy éppen a bajor kormány részéről milyen reakciókat válthat ki, és hogy ezek a reakciók mennyiben rombolhatják a bíróság tekintélyét, vagy csökkenthetik a bíróságba vetett bizalmat. Milyen jelek mutatnak egyértelmủen abba az irányba, hogy a bírók egészen biztosan nem a stratégiai modellnek megfelelően gondolkodtak és cselekedtek?

Először is látni kell, hogy a bíróság döntését megelőzően az ügy egyáltalán nem érdekelte a nyilvános politikai diskurzust sem Bajorországban, sem pedig Németországban. Sem a regionális, sem pedig az országos sajtóban nem lehetett

61 Lembcke i. m. (53. lj.) 47.; Vorländer-Schaal i. m. (55. lj.); Schaal i. m. (42. lj.). 
olvasni az ügyről. Ennek kapcsán Gary Schaal arra utal, hogy a bírósági döntések 1. elrendezhetnek korábban kirobbant konfliktusokat, de 2. akár hozzájárulhatnak korábban kirobbant konfliktusok fokozódásához is.$^{62}$ Másrészt 3 . az is elképzelhető, hogy sem a döntést megelőzően, sem pedig azt követően nem regisztrálnak súlyosabb társadalmi konfliktust az adott ügy kapcsán. A Kruzifix-döntés konfliktusdinamikája viszont inkább egy 4. kategóriába tartozik, hiszen súlyosabb társadalmi konfliktus éppen a döntés hatására robbant ki, a döntést megelőzően nem beszélhetünk arról, hogy az iskolai tantermek falára kihelyezett kereszt éles vitákat váltott volna ki Németországban vagy éppen Bajorországban. Ezt a tényezőt azért érdemes hangsúlyozni, mert a bírák nem a tüzre öntöttek olajat döntésükkel - hiszen még parázs sem létezett.

A társadalmi konfliktus hiánya nagyban hozzájárulhatott ahhoz, hogy a bírákban nem tudatosultak a döntés lehetséges következményei, nem a következményeket mérlegelve hozták meg döntésüket, ebből kifolyólag igencsak meg is lepte őket az a reakcióhullán, amely a döntés nyilvánosságra hozatalát követően indult. Bár bevallásuk szerint annak tudatában voltak, hogy vitatni fogják majd a döntésüket, azzal azonban egyáltalán nem számoltak, hogy ilyen széles körü, jelentős és masszív ellenállásba fognak majd ütközni. ${ }^{63}$ Utólag többen is úgy értékelték, hogy jobb lett volna, ha nyilvános meghallgatásokat is tartanak a Kruzifix-ügyben, mivel akkor már jó előre fel lehetett volna készíteni a közvéleményt, informálódhattak volna az érdeklődők, a sajtó pedig alaposabban körbejárva tálalhatta volna az ügyet, ami azt eredményezhette volna, hogy a közvélemény könnyebben elfogadja a döntést, és egyben annak végrehajtását is „kikényszerítette” volna. ${ }^{64}$

Ezen túlmenően több bíró is úgy vélekedett utólag, hogy nemcsak nyilvános meghallgatásra lett volna szükség, hanem párhuzamos indokolások nyilvánosságra hozatalára is, hiszen ezzel a bíróság azt is megmutatta volna, hogy a döntés végeredményben egy kompromisszumos megoldás volt. ${ }^{65} \mathrm{~A}$ külső körülmények és az esetleges reakciók tudatos számbavételének hiányára utal az is, hogy a Kruzifix-döntést nem választási kampányidőszakban hozták nyilvánosságra, hiszen bajor parlamenti választásokat és országos parlamenti választásokat is egy évvel korábban, 1994 őszén (szeptemberben, illetve októberben) tartottak. Ráadásul a döntést a politikai uborkaszezon közepén, augusztus elején hozták nyilvánosságra.

62 Gary S. Schaal - Kelly Lancaster - Alexander Struwe: Deutungsmacht und Konfliktdynamiken - Eine Analyse der Akzeptanz von Entscheidungen des Bundesverfassungsgerichts. In Christian Boulanger - Anna Schulze - Michael Wrase (szerk.): Die Politik des Verfassungsrechts: Interdisziplinäre und vergleichende Perspektiven auf die Rolle und Funktion von Verfassungsgerichten. Baden-Baden, Nomos, 2013. 196.

63 Dieter Grimm: „Ich bin ein Freund der Verfassung”: Wissenschaftsbiographisches Interview von Oliver Lepsius, Christian Waldhoff und Matthias Roßbach mit Dieter Grimm. Tübingen, Mohr Siebeck, 2017. 154.; Wesel i. m. (47. lj.) 318.; Collings i. m. (49. lj.) 262.

64 Kranenpohl i. m. (19. lj.) 307.

65 Uo. 321. 
Mindezekből kifolyólag nem is számítottak a bírók arra, hogy döntésük esetlegesen politikai csatározások középpontjába kerülhet. Ugyanakkor azért is érte meglepetésként a bírókat a társadalmi ellenállás, mert azt gondolták, hogy a döntés konzisztensen illeszkedik a bíróság korábbi gyakorlatába: a BVerfG ugyanis egy 1973-as döntésében (Kreuz im Gerichtssaal, 1 BvR 308/69) elrendelte már, hogy a bírósági tárgyalótermek faláról le kell venni a kereszteket. Erre a korábbi döntésükre hivatkoztak is az 1995-ös Kruzifix-döntésben, ami még inkább alátámasztja azt az meglátást, amely szerint a bírókban nem tudatosult az, hogy a döntésük bombaként robbanhat, elvégre egy olyan korábbi határozatukra hivatkozva hozták meg a döntésüket, amely semmiféle komolyabb társadalmi reakciót nem váltott ki.

Mindezek alapján tehát ki lehet jelenteni, hogy a Kruzifix-döntés során a bírók egészen biztosan nem mérlegelték annak társadalmi hatását, nem mérték fel azt, hogy milyen reakciókat válthat ki a politikai szereplőkből vagy a bajor választópolgárok egy részéből, hogy döntésükben nem a külső szereplők esetleges válaszreakciója motiválta a bírókat. A racionális döntéselméletre alapozott hipotézisek azért bizonyultak hamisnak a bírói viselkedés tekintetében, mert a bírók nem stratégiailag gondolkodtak, hanem más megfontolások alapján döntöttek.

A kérdés tehát az, hogy ha nem stratégiai-racionális megfontolások vezérelték a bírákat, akkor vajon mi lehet a magyarázat a Kruzifix-döntésre. A választ részben egy alternatív elméleti modellre, részben a döntés szövegére, részben pedig a bírákkal készített interjúkra alapozhatjuk. A bírói viselkedéssel kapcsolatban négyféle magyarázó modellt tart számon a szakirodalom: a formális-jogi modellt, amely szerint a bírói és a bírósági döntést csakis az írott jog (esetünkben az alkotmány) szövegéhez való ragaszkodás, illetve az azokhoz kapcsolódó interpretációs technikák határozzák meg. A bíró a klasszikus megfogalmazás szerint mindössze a törvény szája, aki a döntését azon az alapon hozza meg, hogy mit tartalmaz valójában az alkotmány szövege. Ez a magyarázó modell ma már kissé elavultnak tủnik, helyette viszont a másik három modellt próbálják meg az empirikus jogtudomány művelői alkalmazni. ${ }^{66}$

A fentiekben arra a megállapításra jutottunk, hogy a racionális döntéselméletre alapozott úgynevezett stratégiai modell nem képes magyarázatot adni a Kruzifixdöntésre, hiszen az arra alapozott hipotézisek hamisnak bizonyultak. Van azonban két másik modell, amelyek együttesen némi magyarázatot adhatnak a Kruzifix-döntésre. Az úgynevezett attitüdmodell arra utal, hogy a bíráknak vannak sajátos közpolitikai preferenciái, e modell módosított változata pedig azt állítja, hogy a bírák szavazási magatartását nagymértékben befolyásolhatja az őket jelölő pártszervezetekhez kötődő „hűségük”. ${ }^{67}$ Nos, a Kruzifix-döntés esetében azt látjuk, hogy a BVerfG első szenátusának négy szociáldemokrata bírója, illetve a szabad demokraták által jelölt Johann F. Henschel (aki egyébként a döntés-előkészítő bíró szerepét is betöltötte) alkotta

66 A négy modellről ld. Pócza Kálmán: Az alkotmánybíráskodás gyakorlata összehasonlító szemszögből. In Csink Lóránt - Schanda Balázs (szerk.): Összehasonlitó módszer az alkotmányjogban. Budapest, Pázmány, 2017. 328. 
a szenátusi többséget, a három kereszténydemokrata bíró pedig azt a kisebbséget, akik hevesen ellenezték a többségi döntést. Az attitűdmodell vagy annak módosított változata tehát több-kevesebb magyarázó erővel bírhat ez esetben, hiszen a pártkötődés mentén alakultak ki a törésvonalak. Mivel a szabad demokraták (FDP) vallási ügyekben egyértelműen az állam semlegességének az elvét képviselték, a szociáldemokraták pedig eleve az állam és az egyház szétválasztása mellett kardoskodtak, adja magát a következtetés, hogy a bíróságon belüli törésvonal nem véletlenül tekinthető a pártpolitikai (vagy közpolitikai) törésvonalak leképeződésének.

Ugyanakkor a pártpolitikai vagy közpolitikai preferenciák általában olyan esetekben szoktak nagyobb jelentőséggel bírni, amelyeknek súlyos politikai tétje van. A politikai konfliktusok sokszor a bíróságokon érnek véget, és az attitűdmodell módosított változata szerint a pártpolitikai kötődések ilyen esetekben játszhatnak döntő szerepet. Csakhogy azt is láttuk, hogy a bíróság a Kruzifix-ügy kapcsán nem egy nagypolitikai játszma részese volt, nem jól ismert, országos pártpolitikai küzdelmek döntőbírójaként hozott döntést, hiszen a döntést megelőzően a nyilvánosság számára tulajdonképpen az ügy nem is létezett. Ebből kifolyólag az attitüdmodell pártpolitikai variánsa inkább kevesebb magyarázó erővel bírhat a Kruzifix-döntés esetében. A pártpolitikai attitüdmodell magyarázó erejét továbbá az is gyengíti, hogy a többségi döntést jegyző bírák egy olyan korábbi határozatra hivatkoztak, amelyet egy kereszténydemokrata többségü szenátus fogadott el 1973-ban.

A Kreuz im Gerichtssaal-döntés idején öt kereszténydemokrata és három szociáldemokrata kötődésű bíró alkotta az első szenátust, ráadásul ehhez a döntéshez 1973-ban senki nem füzött különvéleményt (igaz, a különvélemény publikálásának lehetőségét csak két évvel korábban, 1971-ben vezették be). Ezen túlmenően azt is látni kell, hogy a bíróság egyáltalán nem élt a homályos fogalmazás eszközével, amely nagy mozgásteret biztosíthatott volna a döntés érvényesülése tekintetében a bajor törvényhozónak, hanem nagyon expliciten és egyértelműen fogalmazta meg azt a döntését, hogy a keresztet le kell venni az állami fenntartású iskolák faláról.

Az 1973-as Kreuz im Gerichtssaal-döntésre való explicit hivatkozás, a döntés kristálytiszta és egyértelmű nyelvezete, illetve a negatív vallásszabadság teoretikus megalapozása éppen ezért inkább egy másik magyarázó modell érvényességére utal, ez pedig az úgynevezett szerepmodell ${ }^{68} \mathrm{~A}$ bírók e modell szerint olyan hétköznapi emberek, akik nagyon is törődnek azzal, hogy ki mit gondol róluk. Ha a bírókra és a döntéseikre ebből a perspektívából tekintünk, akkor felvetődik a kérdés, hogy a bíró kinek, milyen közönségnek kíván leginkább megfelelni döntései és döntései indoklása révén. Lawrence Baum tézise az, hogy a bírák egyszerre többféle közönségnek is meg kívánnak felelni, vagy akár ki is választhatják, hogy melyik részközönség lenne az a célcsoport, amelyiknek inkább meg kívánnak felelni. ${ }^{69}$ Baum szerint a bírák java része érdekelt abban, hogy a döntése és a döntés indokolása kollégái és a szélesebb

68 Pócza (2017) i. m. (66. lj.) 333.

69 Lawrence Baum: Judges and Their Audiences: A Perspective on Judicial Behavior. Princeton, Princeton University Press, 2008. 50. 
szakmai közönség körében is elismerést nyerjen. Közvetlen bírótársai vagy más bíróságokon dolgozó kollégái olyan közönség lehetnek, amelyik megbecsülését kívánja kivívni döntésével és annak indokolásával.

Persze a bírák számára igazodási pont lehet egy-egy szủkebb társadalmi csoport, közpolitikai nyomásgyakorló csoportok, a média, a szélesebb közvélemény vagy éppen a kormányzati szereplők is. ${ }^{70} \mathrm{~A}$ Kruzifix-döntés esetében ez a szerepmodell magyarázhatja talán a leginkább a többségi döntés mögött álló bírák motivációit, hiszen a korábbi döntésre való hivatkozás a bíróság gyakorlatának a konzisztenciáját hangsúlyozza, a negatív vallásszabadság elméleti megalapozottságú védelme pedig szintúgy arra utal, hogy a bírák elsősorban az értő jogászközösséget kívánták meggyőzni érveikkel. A szerepmodell e magyarázó erejét azonban nemcsak a döntés támasztja alá, hanem a bírák nyilatkozatai is. Uwe Kranenpohl idézi az egyik bírót, aki azt állította az eseményeket követően bő egy évtizeddel, hogy a Kruzifix-döntésre úgy tekintett, mint ami a Kreuz im Gerichtssaal-döntést írja tovább konzekvens módon. ${ }^{71}$ Dieter Grimm pedig a bírósági többség állápontját védelmezve egy 1995. decemberi interjúban kifejezetten arról beszélt, hogy a bíróságnak nem az a feladata, hogy döntéseiben a társadalom többségének a véleményét tükrözze vissza, vagy hogy társadalmi békét teremtsen, hanem az, hogy az alkotmányt következetesen értelmezze. ${ }^{72}$ A döntés-elökészítő bíróként közreműködő és az első szenátust elnöklő Henschel pedig a bajor miniszterelnöknek célozva mondatait úgy fogalmazott, hogy mindenkinek tudomásul kell vennie, hogy Németországban nem csak keresztények élnek. ${ }^{73}$

Összességében tehát azt mondhatjuk, hogy a többségi vélemény mögött álló bírák döntésének hátterében biztosan nem a stratégiai modell magyarázata áll, hanem sokkal inkább a szerepmodell mozgatórugói magyarázhatják meg a döntést. A bírósági többség elsősorban a jogászközösségre figyelve hozta meg határozatát, és írta meg az indokolást, inkább a jogászközösségnek kívántak megfelelni, nem pedig a társadalom többségének, a politikai szereplőknek vagy éppen nyomásgyakorló csoportoknak.

\subsection{Miért viselkedtek deviáns módon a politikai szereplök?}

Arra tehát már megtaláltuk a választ, hogy a racionális döntéselmélet hipotéziseihez képest miért viselkedett deviáns módon a német alkotmánybíróság, arra azonban egyelőre még nem, hogy a stratégiai modell hipotézise miért nem igazolódott be a bírósági döntésre reagáló politikai szereplők esetében. Ahogy fentebb láttuk, a nagy tekintélynek örvendő német alkotmánybíróság döntését tulajdonképpen megkerülte a bajor kormány és a mögötte álló parlamenti többség. A kulcsmomentumnak ebben az ügyben nyilvánvalóan a bajor parlamenti többség törvénymódosítása tekinthető,

70 Baum i. m. (69. lj.) 60.

71 Kranenpohl i. m. (19. lj.) 350.

72 Dieter Grimm: Interview mit der Süddeutschen Zeitung. Süddeutsche Zeitung, 1995. december 9., 284.

73 Collings i. m. (46. lj.) 265. 
hiszen ez tette lehetővé, hogy a feszület továbbra is ott lógjon az iskolai tantermek falán. Ugyanakkor a katolikus vezetők nyilatkozatai, a petíciók és a müncheni tüntetés egyértelműen azt mutatja, hogy nem csak a politikusok ellenállásába ütközött a BVerfG döntése.

A fö kérdés persze mégiscsak az, hogy vajon a bajor törvényhozás miért ment szembe a BVerfG döntésével. A racionális döntéselméleti modellre alapozva ugyanis azt lehetett volna várni, hogy a nagy tekintélynek örvendő bírói testület döntését (félvén a választók büntetésétől) végül elfogadja a bajor parlamenti többség, és leveszik a kereszteket a tantermek faláról (2. hipotézis).

A bíróság döntése után persze elvileg nem is kellett volna semmit sem tennie a bajor törvényhozónak, hiszen a közoktatási törvény vonatkozó passzusát a BVerfG megsemmisítette. Az alkotmányellenes helyzet orvoslásához tehát nem volt szükség olyan komplex eljárásra, amelyben egyszerre több intézménynek is részt kellett volna vennie, hogy megfelelő módon újraszabályozzák a kérdést. Akár fel is tehette volna a kezét a bajor törvényhozás többsége, mondván: nincs mit tenni, a BVerfG megsemmisítette a törvényt, és ezzel lezárult az ügy. Ez gyakorlatilag a feszületek eltávolításával és az alkotmánybírósági döntés teljesülésével lett volna azonos. Hogy a bajor törvényhozás nem hagyta annyiban, az több dolog együttállásának volt köszönhető.

Kétségkívül igaz, hogy a bajor keresztényszocialisták 1962 óta (egészen 2008-ig) megszakítás nélkül egymaguk irányították Bajorországot, azaz minden parlamenti választáson abszolút többséget szereztek a bajor parlamentben, és bár az 1994-es választáson is megőrizték az abszolút többségüket, a II. világháború utáni egyik legrosszabb eredményüket érték el. Az is igaz, hogy a CSU választói valóban igen elkötelezettek voltak: az 1950-es és az 1954-es választásoktól eltekintve stabilan 45 százalék fölött, 1962-től pedig (2008-ig bezárólag) stabilan 50 százalék felett (sokszor 60 százalék körül) kapott voksokat a CSU a bajor tartományi választásokon. ${ }^{74}$ Ám ez a két tényezö önmagában még nem lett volna elég ahhoz, hogy a szövetségi alkotmánybíróság döntésével szembemenve úgy módosítsák a közoktatási törvényt, hogy a feszület továbbra is ott lóghasson a bajor állami közoktatási intézmények falán. Másként fogalmazva azt mondhatjuk, hogy ugyan a 2.1. hipotézis részben megállja a helyét, azaz a keresztényszocialista bajor parlamenti többség valóban részben azért mert

74 Russell J. Dalton - Wilhelm Bürklin: The Two German Electorates: The Social Bases of the Vote in 1990 and 1994. German Politics \& Society, 13. (1995), 1. 79-99.; Rüdiger SchmittBeck - Stefan Weick - Bernhard Christoph: Shaky Attachments: Individual-Level Stability and Change of Partisanship among West German Voters, 1984-2001. European Journal of Political Research, 45. (2006), 4. 581-608.; Herbert Maier: Das Kreuz mit dem Wähler: Erhöhte Komplexität der Wählermärkte als gesamtdeutsche und bayerische Herausforderung. In Gerhard Hopp - Martin Sebaldt - Benjamin Zeitler (szerk.): Die CSU: Strukturwandel, Modernisierung und Herausforderungen einer Volkspartei. Wiesbaden, VS Verlag für Sozialwissenschaften, 2010; Ruth Dassonneville - Marc Hooghe - Bram Vanhoutte: Age, Period and Cohort Effects in the Decline of Party Identification in Germany: An Analysis of a Two Decade Panel Study in Germany (19922009). German Politics, 21. (2012), 2. 209-227.; Martin Elff - Sigrid Roßteutscher: Social Cleavages and Electoral Behaviour in Long-Term Perspective: Alignment without Mobilisation? German Politics, 26. (2017), 1. 12-34. 
szembeszállni a BVerfG döntésével, mert nagyon elkötelezett híveket tudhatott maga mögött, azonban ez az egy tényező önmagában még kevés lett volna ahhoz, hogy a döntést tulajdonképpen ignorálják. A bajor parlamenti többség addig nem tapasztalt engedetlenségéhez szükség volt még pár tényező együttállására.

Egyrészt a szövetségi alkotmánybíróságot már a Kruzifix-döntés előtt is komolyabb kritikák érték más ügyekben 1994 közepe óta, azaz 1995 őszére már több mint egy éve az érdeklődés és a kritikák kereszttüzében állt a bíróság. Más ügyekben többek között vezető bajor politikusok (például Theo Waigelt) is komoly konfliktusba keveredtek a szövetségi alkotmánybírósággal. 1994. július 12-én a BVerfG nem találta alkotmányellenesnek a német haderő külföldi (boszniai és szomáliai) bevetéséről szóló kormányhatározatot, viszont alkotmányos követelményként előírta, hogy a Bundestagnak előzetesen jóvá kell hagynia az ilyen bevetéseket [90 BVerfGE 286 (1994)]. A II. világháború óta először volt szó arról, hogy a Bundeswehr felderítő repülőgépeit külföldön vessék be az Egyesült Nemzetek Szervezete által felügyelt akció keretében a balkáni háború során úgy, hogy nem önvédelemből kell a haderőt mozgósítani. Ezzel a Bundeswehr nemcsak a parlament hadseregévé alakult át, hanem felmerült annak a lehetősége is, hogy német katonák közvetett módon közremüködhetnek olyan külföldi katonai akciókban, amelyekben az ellenfél katonái vagy rosszabb esetben civilek veszíthetik életüket, ráadásul úgy, hogy egy ilyen bevetés nem az önvédelmi klauzulából fakadt.

A politikai elit (elsősorban a geopolitikai helyzetre tekintettel) összességében elfogadta a BVerfG döntését, ugyanakkor ez az ügy közvetlenül és szorosan kapcsolódó előzménye volt egy másik döntésnek, amely viszont már komoly ellenállásba ütközött az akkori Kohl-kormányzat részéről. A Soldaten sind Mörder-ügyben 1994. augusztus 25-én arról hozott döntést a BVerfG első szenátusának három bíróból álló harmadik kamarája (2 BvR 1423/92), hogy a két világháború közötti írófejedelem, Kurt Tucholsky híres mondata („Soldaten sind Mörder” - „A katonák gyilkosok”) sérti-e a Bundeswehr jóhírnevét. A három bíróból álló kamara szinte rutinszerủen találta alkotmányellenesnek azt a bírósági döntést, amelyben az alperest azért ítélték el, mert a teherautójára még az első öbölháború idején egy olyan matricát ragasztott, amelyen a híres Tucholsky-idézet volt olvasható.

A Kohl-kormány külügyminisztere, Klaus Kinkel szerint egy ilyen döntés nagymértékben rombolja a katonaság tekintélyét, a korábbi külügyminiszter Hans-Dietrich Genscher pedig botrányos döntésről beszélt. A honvédelmi miniszter, Volker Rühe elfogadhatatlannak nevezte a döntést, de maga Kohl kancellár is megszólalt az ügyben - igaz, visszafogottan mindössze annyit mondott, hogy németek millióit érinti súlyosan a BVerfG döntése. ${ }^{75} \mathrm{~A}$ CDU honvédelemért felelős elöljárója pedig úgy nyilatkozott: „Ez az ügy a német igazságszolgáltatás szégyene.” ${ }^{\text {”6 }}$ A döntést csak szeptember 19-én hozták nyilvánosságra, ám Grimm, a kamara döntésének kidolgozója,

75 Wesel i. m. (44. lj.) 310.

76 Lamprecht (2011) i. m. (43. lj.) 242. 
ezt követően tömegesen kapott fenyegető leveleket, sőt személyi testőrt is ki kellett rendelni mellé, mivel halálos fenyegetések is akadtak a levelek között. ${ }^{77}$

A nyilvánosságban vita alakult ki a kamara döntése körül, a politikai elit tagjai közül pedig a kereszténydemokraták és a liberálisok is komoly fenntartásaiknak adtak hangot. Ezt a kritikus hangulatot csak fokozta az első szenátus 1995. január 10-i határozata [92 BVerfGE 1 (1995)], amelyben a szenátus a lehető legszűkebb többséggel (5 : 3) mondta ki, hogy az ülőblokád nem értelmezhető erőszakos kényszerítésnek, ennek megfelelően nem is büntethető ilyen alapon. Ebben az esetben ráadásul a bíróság egy korábbi határozatával (BVerfGE 73, 206) szembemenve állapította meg azt, hogy az ülőblokád nem tekinthető erőszakos cselekménynek. A kereszténydemokrata politikusok jelentős része ismételten protestált, ahogy 1995 májusában nem hagyták szó nélkül a Német Demokratikus Köztársaság (NDK) titkosszolgálati vezetőit „felmentő" alkotmánybírósági határozatot sem (2 BvL 19/91). A BVerfG az arányosság elvére hivatkozva több olyan bírósági döntést is megsemmisített, amelyek letöltendő szabadságvesztésre ítéltek több egykori NDK-s titkosszolgálati vezetőt.

Az ügy és a döntés részletei a jelen kontextusban kevéssé érdekesek, a döntés fogadtatása azonban annál inkább: a CDU politikusai ismételten komoly kritikát fogalmaztak meg a karlsruhei bírákkal szemben. Végül pedig még egy döntés, ami a bajor keresztényszocialisták vezetőjét, egyben Kohl kancellár pénzügyminiszterét érintette negatívan: 1995 júniusában ugyanis a BVerfG alkotmányellenesnek minősítette az öröklési, ajándékozási és vagyonadókról szóló törvény 1994 szeptemberében, Waigel (CSU) pénzügyminiszter vezetése alatt módosított bekezdéseit (2 BvL 37/91). ${ }^{78}$ Ne feledjük, a Kruzifix-döntést 1995. augusztus elején hozták nyilvánosságra, eddigre pedig az 1994 nyarától kezdődő időszakban már jó néhány olyan döntés született a BVerfG első vagy második szenátusában, vagy éppen a szenátusok egyik vagy másik kamarájában, amely jócskán felbőszítette a kereszténydemokrata és a keresztényszocialista politikusokat. Azaz a Kruzifix-döntés tulajdonképpen majdnem az utolsó csepp volt a pohárban, illetve azon döntések sorában, amelyek a jobboldali politikusokat céljaik megvalósításában erőteljesen gátolták. ${ }^{79}$

A Kruzifix-döntést megelőző alkotmánybírósági döntések kétségkívül nagyon terheltté tették a jobboldali politikusok és a BVerfG viszonyát. Az előzményeken kívül azonban voltak további tényezők is, amelyek a Kruzifix-döntés után a politikai és társadalmi reakciók eszkalálódásához hozzájárultak. Ahogy fentebb láttuk, 1994 óta több olyan döntés is született, amelyben az egyik vagy a másik szenátus szűk többsége érvényesült csak, ráadásul nemcsak a szavazati arányokat hozták nyilvánosságra, hanem több döntéshez különvéleményt is füztek a bírák. A Kruzifix-döntés maga is azon

77 Grimm i. m. (63. lj.) 147.

78 Lamprecht i. m. (43. lj.) 247.

79 A Soldaten sind Mörder-ügy végül 1995 októberében az első szenátus döntésével zárult (1 BvR 1476), amely az első szenátus harmadik kamarájának döntését tulajdonképpen (más ügyekben) megerősítette, és megsemmisített olyan rendes bírósági döntéseket, amelyek a „Soldaten sind Mörder" szlogen miatt ítéltek el valakit. 
ritka döntések egyike volt, amelyhez különvéleményt is csatoltak a többségi döntéssel egyet nem értő bírák, ráadásul rögtön három különvéleményt, ami az érdeklődők számára egyértelművé tette: a lehető legszűkebb többség $(5: 3)$ mondta ki a verdiktet. ${ }^{80}$

Egy olyan bíróság esetében, amelynél 1971 óta, amióta bevezették a különvélemények intézményét, csak nagyon ritkán fordult elő, hogy a többségi döntéshez különvéleményeket csatoljanak, sokkal nagyobb jelentősége volt a különvéleményeknek, mint azon bíróságok esetében, ahol ez többé-kevésbé megszokott gyakorlattá vált. A Kruzifix-döntés kritizálói nemcsak azt hangsúlyozták, hogy ilyen fontos kérdésben nem lehet szűk többségre alapozva megfelelő döntést hozni, hanem a különvélemények révén komoly érveket is kaptak a kezükbe. A bíróságon belüli nagyon éles törésvonal nyilvánosságra kerülése ebben az esetben nem megnyugtatta a kedélyeket, hanem inkább ahhoz járult hozzá, hogy a többségi döntés kritikusai ne csak a falig menjenek el, hanem azon akár át is, azaz figyelmen kívül hagyják a többség döntését.

Harmadrészt a politikai szereplőkön kívül is volt egy olyan nagyon erős és Bajorországban mélyen beágyazott társadalmi szervezet, amelyik a BVerfG döntésével a legmesszebbmenőkig nem értett egyet: a Katolikus Egyház beágyazottsága és mozgósító ereje Bajorországban minden bizonnyal szintén nagymértékben hozzájárult ahhoz, hogy a döntését heves kritikák érték, és hogy a bajor választópolgárok jelentős része nem megbüntette, hanem inkább támogatta a bíróság döntését tulajdonképpen felülíró bajor parlamenti többséget. Ahogy fentebb láttuk, a Katolikus Egyház aktívan részt vett a döntés elleni aláírások gyüjtésében, a Bajor Katolikus Egyház vezetői gyakran nyilatkoztak meg a nyilvánosság különböző fórumain, sajtóban, televízióban, sőt a müncheni tüntetésen Wetter bíboros fel is szólalt.

A Katolikus Egyház, illetve az Evangélikus Egyház a maga kb. 25-25 millió tagjával még akkor is a legnagyobb társadalmi szervezetek közé tartoztak Németországban, ha aktív tagságuk létszáma jóval alacsonyabb, politikailag is aktív tagjaik száma pedig minden bizonnyal nagyságrendekkel kisebb volt már a 90-es években is ${ }^{81}$ Anyagi és mozgósító erejüket azonban ettől függetlenül nem lehet lebecsülni, ráadásul 1993-ban (a német egyesülést követően) a Német Katolikus Egyház az új politikai és társadalmi helyzetre is tekintettel széles körü konzultációt indított a német társadalom előtt álló kihívásokkal kapcsolatban. ${ }^{82}$ A 90 -es években a katolikus hívők aránya nagymértékben csökkent, javarészt az új, tradicionálisan evangélikus, ám a kommunizmust követő időszakban leginkább vallási értelemben el nem kötelezett

80 Szavazategyenlőség esetén a német $\mathrm{AB}$ eljárása szerint nem hoznak döntést, azaz a felülvizsgált jogszabály marad érvényben.

81 Ulrich Willems: Kirchen. In Thomas von Winter - Ulrich Willems (szerk.): Interessenverbände in Deutschland. Wiesbaden, VS Verlag für Sozialwissenschaften, 2007. 317.

82 Antonius Liedhegener: Veränderte politische Optionen? Kirche und Katholizismus im politischen System der Bundesrepublik Deutschland seit 1989/90. In Manfred Brocker - Hartmut Behr - Mathias Hildebrandt (szerk.): Religion - Staat - Politik: Zur Rolle der Religion in der nationalen und internationalen Politik. Wiesbaden, Westdeutscher Verlag, 2003a. 243.; Antonius Liedhegener: Plural und politisch. Der Katholizismus in der Bundesrepublik Deutschland seit 1989/90. Jahrbuch für Christliche Sozialwissenschaften, 44. (2003b), 53-72. 63. 
tartományok csatlakozásának köszönhetően, az Egyház pedig éppen ezért keresett új csatornákat, amelyek révén a német egyesülést követően a legfontosabb társadalmi problémákról nyilvános eszmecserét kezdeményezhettek.

Ehhez a kezdeményezéshez csatlakozott az Evangélikus Egyház is, azaz azt mondhatjuk, hogy társadalompolitikai értelemben az egyházak a 90-es évek közepén igen aktívak voltak. ${ }^{83} \mathrm{Ha}$ a Katolikus Egyház növekvő társadalmi aktivitásához még hozzávesszük, hogy Bajorországban a katolikus identitás milyen mélyen gyökerezett, vagy azt, hogy bár a szekularizáció kétségkívül a mindig is különc Bajorországot sem kerülhette el, azért a katolikus identitás a 90-es években még masszívan meghatározta a bajor választópolgárok mentalitását, akkor az is könnyen belátható, hogy a bajor választópolgárok miért háborodtak fel tömegesen a BVerfG döntésén. ${ }^{84} \mathrm{~A} 90$-es években a CDU/CSU és az egyházak, illetve a hívők viszonya is még relatíve szorosnak volt mondható, ${ }^{85}$ a kapcsolat a kereszténydemokrata pártok és az egyházak/hívők között majd csak a 2000-es évek elején lazult fel valamelyest, amikor a pártok felismerték, hogy a stabil szavazótábor (részben ismételten csak az új tartományok csatlakozása miatt) már nem fogja tudni kormányra juttatni a kereszténydemokrata erőket, így a vallásos tematika (legalábbis egy időre) némileg veszített a vonzerejéből a kereszténydemokrata politikusok szemében. ${ }^{86}$

Negyedrészt azt sem érdemes figyelmen kívül hagyni, hogy az ügynek akarva-akaratlan is volt egy föderalista dimenziója: mivel az oktatásügy kizárólag tartományi hatáskör volt, így a Kruzifix-döntéshez különvéleményt író bírák mellett a kritikusok egy része is azzal érvelt, hogy a BVerfG tulajdonképpen olyan ügyben hozott döntést, amely egyértelműen és kizárólag tartományi kompetencia. ${ }^{87}$ Ebből kifolyólag a szövetségi szervek a Grundgesetz 72. cikkében található elvre, az életviszonyok egységességének elvére hivatkozva sem szólhatnak bele az oktatási ügyekbe, mivel az teljes mértékben tartományi kompetencia. ${ }^{88}$ A speciális (és speciálisan erős), tradíciókra és nem utolsósorban a katolicizmusra építő bajor identitás a 90-es években még a szekularizáció előrehaladtával is erőteljesen formálta a bajor politikai kultúrát. ${ }^{89}$

83 Antonius Liedhegener: Macht, Moral und Mehrheiten: der politische Katholizismus in der Bundesrepublik Deutschland und den USA seit 1960. Baden-Baden, Nomos, 2006.

84 Maier i. m. (74. lj.) 38.

85 Marcus Gerngroß: (K)eine Bindung auf ewig - die CSU und die Kirchen. In Gerhard Hopp - Martin Sebaldt - Benjamin Zeitler (szerk.): Die CSU: Strukturwandel, Modernisierung und Herausforderungen einer Volkspartei. Wiesbaden, VS Verlag für Sozialwissenschaften, 2010. 91.

86 Liedhegener 2003b i. m. (83. lj.) 66.

87 L. 1 BvR 1087/91 különvélemények: Seidl, Söllner, Haas; Collings i. m. (49. lj.) 261.

88 Otwin Massing: Anmerkungen zu einigen Voraussetzungen und (nichtintendierten) Folgen der Kruzifix-Entscheidung des Bundesverfassungsgerichts. Politische Vierteljahresschrift, 36. (1995), 4. 719-731. 723.

89 Michael Weigl: Tradition und Modernität als Merkmale politischer Kultur. In Nikolaus Werz - Martin Koschkar (szerk.): Regionale politische Kultur in Deutschland: Fallbeispiele und vergleichende Aspekte. Wiesbaden, Springer Fachmedien, 2016. 124.; Manuela Glaab - Michael Weigl: Politik und Regieren in Bayern: Rahmenbedingungen, Strukturmerkmale, Entwicklungen. In Manuela Glaab - Michael Weigl (szerk.): Politik und Regieren in Bayern. Wiesbaden, Springer Fachmedien, 2013. 75. 
Ez a katolicizmusra és tradíciókra építő regionális politikai kultúra és identitás, valamint az a tény, hogy az oktatási kérdések kezelése kizárólagosan tartományi (tehát regionális) kompetenciaként van elkönyvelve Németországban, egészen bizonyosan hozzájárultak ahhoz, hogy a bajor parlamentben az egypárti keresztényszocialista többség szembemenjen a BVerfG döntésével. Történetileg ugyan arról nem lehet beszélni, hogy a bajor politikai elit vagy a bajor politikai intézmények állandó konfliktusban lettek volna a szövetségi alkotmánybírósággal, voltak ugyanis olyan időszakok (főleg az 1970-es években, amikor szövetségi szinten a szociáldemokraták kormányoztak), amikor a bajor keresztényszocialisták is támaszkodhattak a szövetségi alkotmánybíróságra. ${ }^{90}$ Ráadásul azt sem lehet egyértelműen kijelenteni, hogy a BVerfG mindig és következetesen a szövetségi kormány javára döntött volna a föderalizmus kérdését érintő ügyekben. ${ }^{91}$ Az azonban biztos, hogy az 1990-es években nem volt éppen harmonikus a viszony a bajor parlamenti többség és a BVerfG között. ${ }^{92}$

Ebben az értelemben a törésvonalak nagyon egyértelmủen rajzolódtak ki és estek egybe: az egyik oldalon az egypárti, stabil és elkötelezett szavazóbázissal bíró bajor parlamenti többség, amelyik maga mögött tudta a bajor alkotmánybíróság, a Katolikus (sőt részben az Evangélikus) Egyház és a bajor választók túlnyomó többségének a támogatását (ez utóbbiak ráadásul a BVerfG történetében egészen kivételes módon petíciók és tüntetés formájában is hangot adtak a Kruzifix-döntéssel szembeni elégedetlenségüknek), a másik oldalon pedig a BVerfG. Ez a szövetségi alkotmánybírósággal szemben álló intézményi és társadalmi koalíció már elég erősnek tűnt ahhoz, hogy egy olyan gyújtóelegyet jelentsen, amely a bajor parlamenti többséget a szövetségi alkotmánybíróság döntésének felülírására sarkallta.

Végezetül a Kruzifix-ügy azért is érdekes, mert a parlamenti többség nem a nyilvánosság elől „elrejtve” próbálta meg saját akaratát az „utolsó szót” kimondó BVerfG döntése ellenében érvényesíteni, hanem éppen a nyilvánosságra támaszkodva „írta felül" azt. Bár kétségkívül igaz, hogy a szövetségi alkotmánybíróság döntéseit általában tiszteletben tartották a politikai szereplők, azért néhány esetben mégis előfordult, hogy olyan új szabályozást fogadtak el, amellyel tulajdonképpen megkerülték a BVerfG döntését. Azért is érdekesek ezek az esetek, mert a politika iránt valamelyest érdeklődő nyilvánosság ezekben az ügyekben inkább a BVerfG mellett állt.

Ennek következtében a korábbi esetek nem is jártak komolyabb presztízsveszteséggel a BVerfG számára, noha elviekben olyan közérdeklődésre számot tartó ügyekről volt szó, mint a pártfinanszírozás kérdése, a közalkalmazottak nyugdíja, a parlamenti képviselők tanácsadói szerződései vagy éppen az örökösödési adó. Ezen ügyek már az alkotmánybírósági döntés előtt is a nyilvános érdeklődés homlokterében álltak, ám

90 Alexander Wegmaier: Beziehungen zum Bund (2018). Elérhető: https://www.historisches-lexikonbayerns.de/Lexikon/Beziehungen_zum_Bund (A letöltés dátuma: 2020.10. 07.)

91 Stefan Korioth: Die Rechtsprechung des Bundesverfassungsgerichts zum Bundesstaat. In Robert C. van Ooyen - Martin H. W. Möllers (szerk.): Das Bundesverfassungsgericht im politischen System. Wiesbaden, VS Verlag für Sozialwissenschaften, 2015.

Wegmaier i. m. (90. lj.). 
általában olyan politikai érdekkoalíció jött létre, amely miatt a nagy pártok azonos platformra kerülve a szövetségi alkotmánybíróság döntésének megkerülése, felülírása vagy egyszerủ elszabotálása mellett döntöttek. Mivel ezen ügyekben a törésvonalak nem voltak olyan egyértelmü átfedésben, mint a Kruzifix-ügyben, a politikai szereplők is jóval könnyebben lavíroztak az érdekek között, miközben próbálták az ügyet a lehető leginkább alultematizálni vagy kerülni a nyilvánosságban.

\section{Konklúzió}

A bajor feszületügy az Adenauer-korszak óta a BVerfG legnagyobb krízisét okozta, ami átmenetileg az intézmény társadalmi támogatottságának csökkenéséhez is elvezetett. A kortársak ugyan úgy érzékelték, hogy a bajor feszületügyet követően már semmi sem lehet olyan, mint régen volt, az alkotmánybíróságba vetett bizalom olyanynyira megingott, hogy gyökeres változtatásokra lenne szükség, az idő végül mégiscsak a szövetségi alkotmánybíróságnak dolgozott. Pár évvel a feszületügyet követően helyreállt a bizalmi index, a diffúz társadalmi támogatottsága ismét elérte a megszokott, igen magas szintet, a bíróság tehát kiheverte második legnagyobb krízisét, sikerült visszanyernie a választópolgárok bizalmát. Ugyanakkor az is igaz, hogy a krízishez vezető okok feltárása igen sok tanulsággal szolgálhat az alkotmánybíráskodás gyakorlatát, a bírói viselkedést illetően.

A nemzetközi szakirodalomban széles körben elterjedt racionális döntéselméleti modell ugyanis nem volt képes sem előre jelezni, sem pedig utólag megmagyarázni azt, hogy miért és hogyan is alakulhatott ki ez a komoly krízishelyzet. Mind a BVerfG, mind pedig a bajor parlamenti többség deviáns módon viselkedett - ha a normát a racionális döntéselméletre alapozott hipotézisek jelentik. A stratégiai modellre építő magyarázatok ugyan regisztrálják a deviáns esetet, az ahhoz vezető okok feltárásával nem foglalkoznak, hiszen ezek a modellek általában nagy esetszámú kutatások alapján, általános törvényszerűségeket (pontosabban fogalmazva: output-valószínűséget) fogalmaznak meg. A deviáns esetek okainak feltárása így az esettanulmányokra marad. A jelen írás erre vállalkozott, amikor amellett érvelt, hogy a BVerfG feszületügyben meghozott döntését nem a racionális döntéselméleti modell, hanem sokkal inkább a szerepmodell (és részben az attitüdmodell módosított változata) képes megmagyarázni.

A bírák nem stratégiai módon gondolkodtak, hanem a kollégáik és a jogászközösség felé érvelve, döntéseik konzisztenciáját és elméleti megalapozottságát próbálták bizonyítani a döntés indokolásában. Ugyanakkor azt is láttuk, hogy a bajor parlamenti többség is deviáns módon viselkedett, és a nagy tekintélynek örvendő BVerfG döntését egészen egyszerűen megkerülték, elszabotálták, felülírták. A bajor keresztényszocialisták „bátorságát” csak részben magyarázza az, hogy mélyen beágyazott pártról van szó, amelyik elkötelezett hívekkel rendelkezett. A bírósági különvélemények, a szűk bírósági többség, a Katolikus Egyház aktivitása, az ügy föderalizmust és tartományi kompetenciákat érintő jellege, illetve a feszületügy előzményei mind annak 
ágyaztak meg, hogy a folyamat végén a bajor parlamenti többség olyan törvénymódosítást fogadott el, amely végeredményben mégis biztosította azt, hogy Bajorországban kint maradhatott a feszület a tantermek falán.

A BVerfG a csatát elveszítette, a bajor parlamenti többség nem hajolt meg az akarata előtt. Ugyanakkor olyan mély sebeket mégsem szerzett, hogy elvérzett volna: 2020 tavaszán a német alkotmánybírák ugyanis nem egy tartományi kormánnyal, hanem az európai kötvényvásárlási program kapcsán az Európai Központi Bankkal és az Európai Unió Bíróságával húztak ujjat. Ez az ügy pedig nem éppen arról tanúskodik, hogy a német bírák egy újabb (immáron európai méretủ) alkotmányos krízistől féltek volna. Minthogy a BVerfG bizalmi indexe pár éven belül helyreállt, így azt is mondhatnánk, hogy a bíróság (második) legnagyobb krízise tulajdonképpen nem hagyott mély nyomokat a bíróság ítélkezési gyakorlatában.

\section{Irodalomjegyzék}

Allgemeine Geschäftsordnung für die Behörden des Freistaates Bayern (AGO) vom 12 Dezember 2000 (GVBl. S. 873; 2001 S. 28) BayRS 200-21-I (\$\$ 1-38) - Bürgerservice.

Bailey, Michael A. - Maltzman, Forrest: The Constrained Court: Law, Politics, and the Decisions Justices Make. Princeton, Princeton University Press, 2011. DOI: https://doi. org/10.1515/9781400840267

Bartels, Brandon L. - Johnston, Christopher D.: On the Ideological Foundations of Supreme Court Legitimacy in the American Public. American Journal of Political Science, 57. (2013), 1. 184199. DOI: https://doi.org/10.1111/j.1540-5907.2012.00616.x

Bartels, Brandon L. - Kramon, Eric: Does Public Support for Judicial Power Depend on Who Is in Political Power? Testing a Theory of Partisan Alignment in Africa. American Political Science Review, 114. (2020), 1. 144-163. DOI: https://doi.org/10.1017/S0003055419000704

Baum, Lawrence: Judges and Their Audiences: A Perspective on Judicial Behavior. Princeton, Princeton University Press, 2008. DOI: https://doi.org/10.1515/9781400827541

BayEUG: Bayerisches Gesetz über das Erziehungs- und Unterrichtswesen (BayEUG) in der Fassung der Bekanntmachung vom 31 Mai 2000 (GVBl. S. 414, 632) BayRS 2230-1-1-K (Art. 1-125) - Bürgerservice. 2020.

Bennett, Andrew - Checkel, Jeffrey T. (szerk.): Process Tracing: From Metaphor to Analytic Tool. Strategies for Social Inquiry. Cambridge, Cambridge University Press, 2014. DOI: https://doi. org/10.1017/CBO9781139858472

Bergara, Mario - Richman, Barak - Spiller, Pablo T.: Modeling Supreme Court Strategic Decision Making: The Congressional Constraint. Legislative Studies Quarterly, 28. (2003), 2. 247-280. DOI: https://doi.org/10.3162/036298003X200881

Bickel, Alexander M.: The Least Dangerous Branch: The Supreme Court at the Bar of Politics. Indianapolis, Bobbs-Merrill, 1962.

Carrubba, Clifford J. - Zorn, Christopher J.: Executive Discretion, Judicial Decision Making, and Separation of Powers in the United States. Journal of Politics, 72. (2010), 3. 812-824. DOI: https:// doi.org/10.1017/S0022381610000186

Casillas, Christopher J. - Enns, Peter K. - Wohlfarth, Patrick C.: How Public Opinion Constrains the US Supreme Court. American Journal of Political Science, 55. (2011), 1. 74-88. DOI: https:// doi.org/10.1111/j.1540-5907.2010.00485.x 
Clark, Tom S.: The Separation of Powers, Court Curbing, and Judicial Legitimacy. American Journal of Political Science, 53. (2009), 4. 971-989. DOI: https://doi.org/10.1111/j.15405907.2009.00411.x

Clark, Tom S.: The Limits of Judicial Independence: Political Economy of Institutions and Decisions. Cambridge, Cambridge University Press, 2010. DOI: https://doi.org/10.1017/ CBO9780511761867

Collier, David: Understanding Process Tracing. Political Science E Politics, 44. (2011), 4. 823-830. DOI: https://doi.org/10.1017/S1049096511001429

Collings, Justin: Democracy's Guardians: A History of the German Federal Constitutional Court, 1951-2001. Oxford, Oxford University Press, 2015. DOI: https://doi.org/10.1093/acprof:oso/9780198753377.001.0001

Dahl, Robert A.: Decision-Making in a Democracy: The Supreme Court as a National Policy-Maker. Journal of Public Law, 6. (1957), 2. 279-295.

Dalton, Russell J. - Bürklin, Wilhelm: The Two German Electorates: The Social Bases of the Vote in 1990 and 1994. German Politics \& Society, 13. (1995), 1. 79-99.

Das Kreuz ist der Nerv. Der Spiegel, 1995. augusztus 14. Elérhető: https://www.spiegel.de/spiegel/ print/d-9206287.html (A letöltés dátuma: 2020. 10. 07.)

Dassonneville, Ruth - Hooghe, Marc - Vanhoutte, Bram: Age, Period and Cohort Effects in the Decline of Party Identification in Germany: An Analysis of a Two Decade Panel Study in Germany (1992-2009). German Politics, 21. (2012), 2. 209-227. DOI: https://doi.org/10.1080/096 44008.2012.679659

Driscoll, Amanda - Nelson, Michael J.: Judicial Selection and the Democratization of Justice: Lessons from the Bolivian Judicial Elections. Journal of Law and Courts, 3. (2015), 1. 115-148. DOI: https://doi.org/10.1086/679017

Driscoll, Amanda - Nelson, Michael J.: The Costs and Benefits of Court Curbing: Experimental Evidence from the United States (2018). Elérhetö: https://pdfs.semanticscholar.org/d2b8/ ab6532c4957339bd52d7ad0897b3f425fa73.pdf (A letöltés dátuma: 2020. 10. 07.)

Elff, Martin - Roßteutscher, Sigrid: Social Cleavages and Electoral Behaviour in Long-Term Perspective: Alignment without Mobilisation? German Politics, 26. (2017), 1. 12-34. DOI: https:// doi.org/10.1080/09644008.2016.1190833

Epstein, Lee - Martin, Andrew: Does Public Opinion Infuence the Supreme Court? Possibly Yes (But We're Not Sure Why). University of Pennsylvania Journal of Constitutional Law, 13. (2010), 2. 263-281.

Friedman, Barry: The Will of the People: How Public Opinion has Influenced the Supreme Court and Shaped the Meaning of the Constitution. New York, Farrar, Straus and Giroux, 2009.

George, Alexander L. - Bennett, Andrew: Case Studies and Theory Development in the Social Sciences. Cambridge, MIT, 2005.

Gerhard, Rudolf: Die Medien haben Einfluss auf die Justiz - aber welchen? Eine Umfrage und ihre Ergebnisse. In Organisationsbüro der Strafverteidigervereinigungen (szerk.): Erosion der Rechtsstaatlichkeit: Werteverfall oder Paradigmenwechsel? Berlin, Schriftenreihe der Strafverteidigervereinigungen, 2002. 249-260.

Gerngroß, Marcus: (K)eine Bindung auf ewig - die CSU und die Kirchen. In Hopp, Gerhard - Sebaldt, Martin - Zeitler, Benjamin (szerk.): Die CSU: Strukturwandel, Modernisierung und Herausforderungen einer Volkspartei. Wiesbaden, VS Verlag für Sozialwissenschaften, 2010. 77-98. DOI: https://doi.org/10.1007/978-3-531-92521-9_5 
Glaab, Manuela - Weigl, Michael: Politik und Regieren in Bayern: Rahmenbedingungen, Strukturmerkmale, Entwicklungen. In Glaab, Manuela - Weigl, Michael (szerk.): Politik und Regieren in Bayern. Wiesbaden, Springer Fachmedien, 2013. 19-96. DOI: https://doi.org/10.1007/9783-531-93414-3

Graber, Mark A.: The Nonmajoritarian Difficulty: Legislative Deference to the Judiciary. Studies in American Political Development, 7. (1993), 1. 35-73. DOI: https://doi.org/10.1017/ S0898588X00000687

Grimm, Dieter: Interview mit der Süddeutschen Zeitung. Süddeutsche Zeitung, 1995. december 9., 284.

Grimm, Dieter: „Ich bin ein Freund der Verfassung”: Wissenschaftsbiographisches Interview von Oliver Lepsius, Christian Waldhoff und Matthias Roßbach mit Dieter Grimm. Tübingen, Mohr Siebeck, 2017.

Hall, Matthew E. K.: The Semiconstrained Court: Public Opinion, the Separation of Powers, and the US Supreme Court's Fear of Nonimplementation. American Journal of Political Science, 58. (2014), 2. 352-366. DOI: https://doi.org/10.1111/ajps.12069

Hall, Matthew E. K. - Ura, Joseph D.: Judicial Majoritarianism. Journal of Politics, 77. (2015), 3. 818-832. DOI: https://doi.org/10.1086/681437

Helmke, Gretchen: Institutions on the Edge: The Origins and Consequences of Inter-Branch Crises in Latin America. Cambridge, Cambridge University Press, 2017. DOI: https://doi. org/10.1017/9781139031738

Hönnige, Christoph - Gschwend, Thomas: Das Bundesverfassungsgericht im politischen System der BRD - ein unbekanntes Wesen? Politische Vierteljahresschrift, 51. (2010), 3. 507-530. DOI: https://doi.org/10.1007/s11615-010-0030-z

Jay, John - Hamilton, Alexander - Madison, James: A föderalista. Budapest, Európa, 1998.

Jung, Otmar: Volksabstimmungen (2006). Elérhető: https://www.historisches-lexikon-bayerns.de/ Lexikon/Volksabstimmungen\#17 (A letöltés dátuma: 2020. 10. 07.)

Kapiszewski, Diana - Taylor, Matthew M.: Compliance: Conceptualizing, Measuring, and Explaining Adherence to Judicial Rulings. Law E Social Inquiry, 38. (2013), 4. 803-835. DOI: https:// doi.org/10.1111/j.1747-4469.2012.01320.x

Kastellec, Jonathan P.: Empirically Evaluating the Countermajoritarian Difficulty: Public Opinion, State Policy, and Judicial Review before Roe v. Wade. Journal of Law and Courts, 4. (2016), 1. 1-42. DOI: https://doi.org/10.1086/683466

Kepplinger, Hans M. - Zerback, Thomas: Der Einfluss der Medien auf Richter und Staatsanwälte. Publizistik, 54. (2009), 2. 216-239. DOI: https://doi.org/10.1007/s11616-009-0036-y

Koltay András: Európa és a feszület jele: a Lautsi and Others v. Italy ügy alapvető kérdéseiről. In Tattay Levente - Pogácsás Anett - Molnár Sarolta (szerk.): Pro vita et scientia. Ünnepi kötet Jobbágyi Gábor 65. születésnapja alkalmából. Budapest, Szent István Társulat, 2012. 127-153.

Korioth, Stefan: Die Rechtsprechung des Bundesverfassungsgerichts zum Bundesstaat. In van Ooyen, Robert C. - Möllers, Martin H. W. (szerk.): Das Bundesverfassungsgericht im politischen System. Wiesbaden, VS Verlag für Sozialwissenschaften, 2015. 391-405. DOI: https://doi. org/10.1007/978-3-531-90289-0_28

Kranenpohl, Uwe: Hinter dem Schleier des Beratungsgeheimnisses: Der Willensbildungs- und Entscheidungsprozess des Bundesverfassungsgerichts. Wiesbaden, VS Verlag für Sozialwissenschaften, 2010. DOI: https://doi.org/10.1007/978-3-531-92242-3 
Krehbiel, Jay N.: The Politics of Judicial Procedures: The Role of Public Oral Hearings in the German Constitutional Court. American Journal of Political Science, 60. (2016), 4. 990-1005. DOI: https://doi.org/10.1111/ajps.12229

Krehbiel, Jay: Elections, Public Awareness, and the Efficacy of Constitutional Review. Journal of Law and Courts, 7. (2019), 1. 53-79. DOI: https://doi.org/10.1086/699241

Lamprecht, Rolf: Das Bundesverfassungsgericht. Geschichte und Entwicklung. Bonn, Bundeszentrale für politische Bildung, 2011.

Lembcke, Oliver: Über das Ansehen des Bundesverfassungsgerichts: Ansichten und Meinungen in der Öffentlichkeit 1951-2001. Berlin, Berliner Wissenschafts, 2006. DOI: https://doi.org/10.13140/ RG.2.1.1447.4728

Lemieux, Scott E. - Watkins, David J.: Beyond the "Countermajoritarian difficulty": Lessons from Contemporary Democratic Theory. Polity, 41. (2009), 1. 30-62. DOI: https://doi.org/10.1057/ pol.2008.25

Liedhegener, Antonius: Veränderte politische Optionen? Kirche und Katholizismus im politischen System der Bundesrepublik Deutschland seit 1989/90. In Brocker, Manfred - Behr, Hartmut - Hildebrandt, Mathias (szerk.): Religion - Staat - Politik: Zur Rolle der Religion in der nationalen und internationalen Politik. Wiesbaden, Westdeutscher Verlag, 2003a. 237-262. DOI: https://doi.org/10.1007/978-3-322-91612-9_13

Liedhegener, Antonius: Plural und politisch. Der Katholizismus in der Bundesrepublik Deutschland seit 1989/90. Jahrbuch für Christliche Sozialwissenschaften, 44. (2003b), 53-72.

Liedhegener, Antonius: Macht, Moral und Mehrheiten: der politische Katholizismus in der Bundesrepublik Deutschland und den USA seit 1960. Baden-Baden, Nomos, 2006.

Lovell, George I.: Legislative Deferrals: Statutory Ambiguity, Judicial Power, and American Democracy. Cambridge, Cambridge University Press, 2003.

Maier, Herbert: Das Kreuz mit dem Wähler: Erhöhte Komplexität der Wählermärkte als gesamtdeutsche und bayerische Herausforderung. In Hopp, Gerhard - Sebaldt, Martin - Zeitler, Benjamin (szerk.): Die CSU: Strukturwandel, Modernisierung und Herausforderungen einer Volkspartei. Wiesbaden, VS Verlag für Sozialwissenschaften, 2010. 29-46. DOI: https://doi. org/10.1007/978-3-531-92521-9_2

Massing, Otwin: Anmerkungen zu einigen Voraussetzungen und (nichtintendierten) Folgen der Kruzifix-Entscheidung des Bundesverfassungsgerichts. Politische Vierteljahresschrift, 36. (1995), 4. 719-731.

McGoldrick, Dominic: Religion in the European Public Square and in European Public Life: Crucifixes in the Classroom? Human Rights Law Review, 11. (2011), 3. 451-502. DOI: https://doi. org/10.1093/hrlr/ngr024

McGuire, Kevin T. - Stimson, James A.: The Least Dangerous Branch Revisited: New Evidence on Supreme Court Responsiveness to Public Preferences. Journal of Politics, 66. (2004), 4. 10181035. DOI: https://doi.org/10.1111/j.1468-2508.2004.00288.x

Mishler, William - Sheehan, Reginald S.: The Supreme Court as a Countermajoritarian Institution? The Impact of Public Opinion on Supreme Court Decisions. American Political Science Review, 87. (1993), 1. 87-101. DOI: https://doi.org/10.2307/2938958

Patzelt, Werner J.: Warum mögen die Deutschen ihr Verfassungsgericht so sehr? In van Ooyen, Robert C. - Möllers, Martin H. W. (szerk.): Handbuch Bundesverfassungsgericht im politischen System. Wiesbaden, Springer Fachmedien, 2015. 313-331. DOI: https://doi.org/10.1007/978-3658-05703-9_19 
Pócza Kálmán: Politika és alkotmánybíróság: a Bundesverfassungsgericht létrejötte. Külügyi Szemle, 13. (2014), 1. 111-131.

Pócza Kálmán: Az alkotmánybíráskodás gyakorlata összehasonlító szemszögből. In Csink Lóránt - Schanda Balázs (szerk.): Összehasonlító módszer az alkotmányjogban. Budapest, Pázmány, 2017. 311-355.

Schaal, Gary S.: Crisis! What Crisis? Der „Kruzifix-Beschluss” und seine Folgen. In van Ooyen, Robert C. - Möllers, Martin H. W. (szerk.): Das Bundesverfassungsgericht im politischen System. Wiesbaden, VS Verlag für Sozialwissenschaften, 2015. 175-186. DOI: https://doi. org/10.1007/978-3-531-90289-0_13

Schaal, Gary S. - Lancaster, Kelly - Struwe, Alexander: Deutungsmacht und Konfliktdynamiken Eine Analyse der Akzeptanz von Entscheidungen des Bundesverfassungsgerichts. In Boulanger, Christian - Schulze, Anna - Wrase, Michael (szerk.): Die Politik des Verfassungsrechts: Interdisziplinäre und vergleichende Perspektiven auf die Rolle und Funktion von Verfassungsgerichten. Baden-Baden, Nomos, 2013. 187-216. DOI: https://doi.org/10.5771/9783845247892-187

Schäffer, Fritz: Bekenntnisschule (2006). Elérhető: https://www.historisches-lexikon-bayerns.de/ Lexikon/Bekenntnisschule (A letöltés dátuma: 2020. 10. 07.)

Schäffer, Fritz: Gemeinschaftsschule (2006). Elérhető: https://www.historisches-lexikon-bayerns. de/Lexikon/Gemeinschaftsschule (A letöltés dátuma: 2020. 10. 07.)

Schanda Balázs - Koltay András: A Lautsi-ügy a feszületről az állami iskola osztálytermében: a vallási jelképek használatának megengedettsége a semleges állam közéletében. Jogesetek Magyarázata, 2. (2011), 4. 77-85.

Schmitt-Beck, Rüdiger - Weick, Stefan - Christoph, Bernhard: Shaky Attachments: IndividualLevel Stability and Change of Partisanship among West German Voters, 1984-2001. European Journal of Political Research, 45. (2006), 4. 581-608. DOI: https://doi.org/10.1111/j.14756765.2006.00310.x

Schroeder, Philipp A.: The Political Constraints on Constitutional Review. Doktori értekezés (2019). Elérhető: https://discovery.ucl.ac.uk/id/eprint/10078526 (A letöltés dátuma: 2020. 10. 07.)

Spriggs, James F.: Explaining FederalBureaucratic Compliance with SupremeCourt Opinions. Political Research Quarterly, 50. (1997), 3. 567-593. DOI: https://doi.org/10.1177/106591299705000305

Söder ist offen für Kritik am „Kreuzerlass”. Domradio, 2019. április 20. Elérhető: https://www.domradio.de/themen/kirche-und-politik/2019-04-20/wir-haben-das-sehr-liberal-gehandhabt-soeder-ist-offen-fuer-kritik-am-kreuzerlass (A letöltés dátuma: 2020. 10. 07.)

Söder, Markus : Bayern schreibt Kreuze in allen Staatsbehörden vor. Die Zeit, 2018. április 24. Elérhető: https://www.zeit.de/gesellschaft/zeitgeschehen/2018-04/markus-soeder-csu-kreuz-christentum-behoerden-bayern (A letöltés dátuma: 2020. 10. 07.)

Staton, Jeffrey K.: Judicial Policy Implementation in Mexico City and Mérida. Comparative Politics, 37. (2004), 1. 41-60. DOI: https://doi.org/10.2307/4150123

Staton, Jeffrey K. - Vanberg, Georg: The Value of Vagueness: Delegation, Defiance, and Judicial Opinions. American Journal of Political Science, 52. (2008), 3. 504-519. DOI: https://doi.org/10.1111/j.1540-5907.2008.00326.x

Sternberg, Sebastian: No Public, No Power? Analyzing the Importance of Public Support for Constitutional Review with Novel Data and Machine Learning Methods. Doktori értekezés (2019). Elérhető: https://madoc.bib.uni-mannheim.de/52329 (A letöltés dátuma: 2020. 10. 07.)

Sternberg, Sebastian - Gschwend, Thomas - Wittig, Caroline - Engst, Benjamin G.: Zum Einfluss der öffentlichen Meinung auf Entscheidungen des Bundesverfassungsgerichts. Eine Analyse 
von abstrakten Normenkontrollen sowie Bund-Länder-Streitigkeiten 1974-2010. Politische Vierteljahresschrift, 56. (2015), 4. 570-598. DOI: https://doi.org/10.5771/0032-3470-2015-4-570

Supp, Barbara: Heiliger Edmund, bitt' für uns. Der Spiegel, 1995. október 2. Elérhető: https://www. spiegel.de/spiegel/print/d-9223884.html (A letöltés dátuma: 2020. 10. 07.)

Trochev, Alexei: Judging Russia: The Role of the Constitutional Court in Russian Politics 1990-2006. Cambridge, Cambridge University Press, 2008. DOI: https://doi.org/10.1017/ CBO9780511511226

Vanberg, Georg: Legislative-Judicial Relations: A Game-Theoretic Approach to Constitutional Review. American Journal of Political Science, 45. (2001), 2. 346-361. DOI: https://doi. org/10.2307/2669345

Vanberg, Georg: The Politics of Constitutional Review in Germany. Political Economy of Institutions and Decisions. Cambridge, Cambridge University Press, 2005. DOI: https://doi.org/10.1017/ CBO9780511510427

Vanberg, Georg: Establishing and Maintaining Judicial Independence. In Caldeira, Gregory A. - Kelemen, R. Daniel - Whittington, Keith E. (szerk.): The Oxford Handbook of Law and Politics. Oxford, Oxford University Press, 2008. 99-118. DOI: https://doi.org/10.1093/oxfordhb/9780199208425.003.0007

Vanberg, Georg: Constitutional Courts in Comparative Perspective: A Theoretical Assessment. Annual Review of Political Science, 18. (2015), 1. 167-185. DOI: https://doi.org/10.1146/annurevpolisci-040113-161150

Vorländer, Hans - Schaal, Gary S.: Integration durch Institutionenvertrauen? In Vorländer, Hans (szerk.): Integration durch Verfassung. Wiesbaden, VS Verlag für Sozialwissenschaften, 2002. 343-374. DOI: https://doi.org/10.1007/978-3-322-80409-9_14

Wegmaier, Alexander: Beziehungen zum Bund (2018). Elérhető: https://www.historisches-lexikonbayerns.de/Lexikon/Beziehungen_zum_Bund (A letöltés dátuma: 2020.10.07.)

Weigl, Michael: Tradition und Modernität als Merkmale politischer Kultur. In Werz, Nikolaus - Koschkar, Martin (szerk.): Regionale politische Kultur in Deutschland: Fallbeispiele und vergleichende Aspekte. Wiesbaden, Springer Fachmedien, 2016. 119-140. DOI: https://doi. org/10.1007/978-3-658-10468-9_6

Wesel, Uwe: Der Gang nach Karlsruhe. Das Bundesverfassungsgericht in der Geschichte der Bundesrepublik. München, Karl Blessing, 2004.

Whittington, Keith E.: "Interpose Your Friendly Hand": Political Supports for the Exercise of Judicial Review by the United States Supreme Court. American Political Science Review, 99. (2005), 4. 583-596. DOI: https://doi.org/10.1017/S0003055405051890

Willems, Ulrich: Kirchen. In von Winter, Thomas - Willems, Ulrich (szerk.): Interessenverbände in Deutschland. Wiesbaden, VS Verlag für Sozialwissenschaften, 2007. 316-340. DOI: https://doi. org/10.1007/978-3-531-90602-7_12 